\title{
Kapitalizm ve Tüketim Temelinde Yükselen Tüketici Hakları
}

\section{Gaining Popularity of Consumer Rights Based on Capitalism and Consumption}

\author{
Özlem Küçük ${ }^{\mathrm{a}, *}$ \\ a Öğr. Gör. Dr., Kocaeli Üniversitesi, Hukuk Fakültesi, Adalet MYO. 41001, İzmit/KOCAELİ \\ ORCID: 0000-0002-7717-2439
}

\section{MAKALE BİLGİSİ \\ Makale Geçmişi: \\ Başvuru tarihi: 08 Temmuz 2020 \\ Düzeltme tarihi: 17 Kasım 2020 \\ Kabul tarihi: 27 Kasım 2020}

Anahtar Kelimeler:

Tüketim

Kapitalizm

İnovasyon

Sosyal Haklar ve Tüketici Hakları
ÖZ

21.Yüzyıl karşımıza yeni bir kördüğüm çıkarır. Buluş ve teknolojik ilerlemenin daha önce hiç görülmemiş düzeylere ulaştığı günümüzde, bir yandan yaşamda sihirli bir değnek gibi daha fazla konfor ve refah sağlanırken, diğer yandan yok ettiği meslekler, değerler ve eşitsizlikler insanlığı tehdit etmektedir. Bugün, hayatımızın her yönünü etkileyen teknoloji yeni bir inovasyon hızıyla eşitsizlik ve acımasız rekabet üretirken dünyayı belirsizliğe sürüklemektedir. Emeğin bir üretim faktörü olarak değerini korumakta zorlandığı, sosyal hak öznesi olan sanayi işçisinin yerini beşerî sermayenin aldığı çağımızda, üretim ve tüketim arasındaki ilişki ise yeniden düzenlenmektedir. Nitekim, alım gücü azalan ve kargaşaya neden olabilecek toplumlar, tüketimi tehdit etmekte ve Dünya Bankası başta olmak üzere ekonomik büyümenin sürdürülebilirliği için bu yüksek üretim hızını karşılayacak bir tüketim pazarı desteklenmektedir.

\section{A B S T R A C T}

There has been new political, social and economical impasses, which permanently need to solve in the 21 th century. The Keynesian agreement between consumption and production has ended. While the pace of technological development with innovations in production process at the turn of the 21 st century, digitalization and Artificial Intelligence causing fierce competition and inequality by leaving workers behind. The main issue is that how we can sustain the global economic growth based on free market economy. In this case, a new consumption market is required to meet the reduced costs and increased production rate. The same time, the gaining popularity of consumer law, is provided by carrying the concept of consumer right beyond social rights.
Consumption

Capitalism

Innovation

Social Rights and Consumer Rights

\section{Giriş}

Kiely’ye göre, “yeni teknolojiler, bir yandan üretimde gerekli işçilik süresini azaltırken, aynı zamanda emeği sömürür ve tüketimi artırır, diğer yandan çevreye zarar vermek gibi çelişkili etkiler üretmektedir” (Kiely, 1999: 40). Bauman ise, tüketim kavramının özeliklerini şu şekilde ifade etmektedir. İlk özelliği, bazı ihtiyaçlarımızı karşılamak ya da tatmin etmek üzere, bir şeyleri para ile satın alarak bu şeyleri özel mülkiyeti haline getirmek, ikinci özelliği, tüketilen şeyin madden sona ermesi ya da tüketilen şeye olan ihtiyaç ya da isteğin azalması ile sona ermesidir (Bauman, 1999: 39-40). Baudrillard, tüketici toplumu ile ilgili daha derin ve sosyolojik bir bakış açısına sahiptir. Ona göre, tüketime olan inanç yeni bir unsurdur. Keza, genç nesiller, artık sadece malları değil, doğal bolluk hakkını da miras almaktadır. Bugün çevremizde, nesnelerin, hizmetlerin ve maddi malların çoğalmasıyla oluşan bir tür fantastik tüketim ve göze çarpan bolluk var ve bu da insan türünün ekolojisinde temel bir mutasyona işaret etmektedir. Tüketimin, israf ve daha fazla istif, en göze çarpan özelliklerdir. Büyük mağazalar ise konserve yiyecekler, giysiler, gıda maddeleri ve hazır giyim bolluğu ile bu bolluğun geometrik odağı olan ilkel manzara gibidir (Baudrillard, 1998: 25-26 ve 32). 2001 yılından beri kişisel yaşam, aile öyküleri ve yaşam tarzları ile ilgili reality

\footnotetext{
* Sorumlu yazar/Corresponding author.

e-posta: ozlem.akucuk@gmail.com
} 
türünde programlara ağırlık veren TLC, Discovery Communication'a ait bir ABD menşeli kablo ve uydu televizyon kanalıdır. Bilhassa medya araştırmaları alanında yer alan bilim insanları bu tarz televizyon kanallarının modern kültür üzerindeki etkilerini sorgulamaktadırlar (Lundy, Ruth ve Park, 2008: 208 ve 215). TLC TV, 'Kupon Çılgınlığı' isimli programında çok büyük miktarda kupon toplayan kimseleri anlatmaktadır. Mümkün olduğu kadar az ödeyip, mümkün olduğu kadar daha çok satın almak için çöplerden bile kupon toplayan kişilerdir bunlar. 15 yaşındaki Broderic isimli genç öğrenci, kuponlarını kimsenin karıştırmaması için geceleri yastığının altına koyduğunu söylemektedir. Küçük bir stok deposu olan bu genç, bu stoğun değerinin aşağı yukarı 5.400 \$ iken, sadece 100 \$ ödediğini ifade etmektedir. Stokta 244 adet kadın pedi, pek çok şekerleme, diş macunu, kutu içecek, yiyecek ve envaitürlü ürün bulunmaktadır. Broderic, ailesi satın aldığı yiyecekleri beğenmesede (markette indirimde olmayan ve aile üyelerinin birisinin sepete koyduğu turşuyu çıkarır), eve yiyecek getirdiği için kupon toplamasına göz yumduklarını ifade etmektedir. Entresan olan ise, kupon çılgınlarının kupon biriktirip çok fazla ürün satın alarak, ciddi tasarruflar elde ettiklerini düşünmesi ve kendini değerli hissetmesidir. Ancak, zaman zaman despot bir kişiliğe bürünen kupon biriktiricisi, aile bireylerini üzerken, uzun vadede kupon biriktiriciliği ve istif pekçok sorunu beraberinde getirebilir (https://www.tlctv.com.tr/kuponcilginligi/4-sezon-2-bolum).

Nitekim yeni arzular üreterek varolan kapitalizm, onaylanmaya muhtaç değiş̧ken kimliklere yol açar (Kılıç, 2011: 509).

Daha çok satın alarak, daha çok tasarruf edildiği yönünde oluşturulan algıya, belki de en güzel örneklerden birisi, Winx çizgi film serisidir. Bir İtalyan yapımı olan ve Nickelodeon'un sahibi Amerikan medya şirketi Viacom tarafindan belli bir payı satın alınan Winx Club film serisi, periler, cadılar ve diğer efsanevi yaratıkların yaşadığı büyülü bir evreni konu alır. Tek Boynuzlu Atın Sırrı isimli bölümünde geçen konuşma kupon biriktiricilerin daha fazla satın alma hakkındaki görüşleri ile birebir uyuşmaktadır.

-Stella: "İnanamıyorum, indirimde olan herşeyde indirim yapıyorlar. Bu ne demek biliyormusun?"

-Bloom: "Hızlı alışveriş turumuz, sonsuz bir yolculuğa dönüşüyor mu demek?’ᄀ

—Stella: "Hayır, ne kadar çok alırsak, o kadar çok tasarruf ediyoruz, demek."

Tek Boynuzlu Atın Sırrı bölümünde; aşırı tüketimin özendirilmesi ile gerçekte küresel ısınma nedeniyle nesli tükenmekte olan pandaların. hayali bir düşmandan kurtarılması arasında bir tezatlık vardır. Zira Winx perileri, kötü bir sihir yapılmış tek boynuzlu at tarafından ölümle tehdit edilen yavru pandaları kurtarmak üzere mücadele etmektedir. Bir tarafta yaşadığı doğayı ve hayatı korumak üzere seferber olmuş periler, diğer tarafta ne kadar satın alırsak o kadar tasarruf ederiz şeklindeki slogan vardır. Ancak gerçek hayatta, tek boynuzlu at değil, aşırı tüketimi karşılamak üzere aşırı üretimin neden olduğu küresel 1sınma pandalarının hayatını tehdit etmektedir (Winx Club, 2016: https://www.youtube.com/watch?v=Zt_5JuAw4Zg).
21. yüzyılda hiç olmadığg kadar tüketim artmış, daha fazla çevresel ve sosyal sorunlar ile insanlık karşı karşıya kalmıştır. Sanayi 4.0, pek çok alanda yapay zekâ algoritmalarının kullanımını sağlarken verimlilik artmış, maliyetler nispeten gerilemiş, enformasyon teknolojisinde yaşanan yenilikler ise aşırı tüketimi desteklemiştir. Böylelikle nefsini kontrol edemeyen insanoğlu ekonomik, sosyal ve doğal çevresine zarar vermektedir. Oysaki günümüzde gerek üretim gerekse tüketim, sermaye biriktirme, üstünlük ve rekabet aracı olarak görülmektedir. Modern insan ise "yaşamdan doğal olarak mutlu olmasının" acımasızca ortadan kaldırıldığı, bir bürokratik düzen içinde bir demir kafes de kapana sıkışmış durumdadır (Weber, 1992: 123; Kaval, 2019: 157,164).

Ancak, aşırı tüketim yeterli düzeyde istihdama yol açmamaktadır. Günümüzde artan işsizlik, yoksulluk ve eşitsizlik önemli meselelerdir. Bununla beraber, geleceğe yönelik endişeler arasında, gig ekonominin yükselişi, ülkelerin rekabet avantajı sağlayan üstünlüklerinin azalması, sosyal güvencenin ortadan kalkması, ekonomik durgunluk, otomasyon, üretimin farklı ülkelere taşınması, artan göç hareketleri bulunmaktadır. Gig ekonomi, geleneksel işgücü ile tam zamanlı çalışma ve sosyal hakların (sağlık, güvenlik, yasal tatil izni...) hiçbirine sahip olmayan, genellikle bir işyerinde olmadan uzaktan çalışma ile kazanç üreten ve işveren için işgücü maliyetinden tasarrufu sağlayan esnek ekonomidir. Böylece, enformasyon teknolojilerinin bir sonucu olarak "çevrimiçi işgücü platformları" ile uzaktan kontrol edilen bir gig ekonomi üretilmiştir. $\mathrm{Bu}$ durum, üretim verimliliğini artırırken, kayıtlı iş istihdamı oranlarını düşürmekte ve emeğin zayıf konumunu kötüleştirmektedir. Bu bağlamda, 1970-1994 arasındaki dönemde, sanayi sektörü istihdam oranları AB ülkelerinde \%30'dan \%20'ye Amerika Birleşik Devletleri'nde ise \%28'den \%16'ya gerilemiştir (Wood, Graham ve Amir Anvar, 2020: 74-75; Özkan, 2020, Bauman, 1999: 41).

Estlund'a göre, robotik, yapay zekâ ve makine öğrenimindeki ilerlemeler, işgücünün büyük çoğunluğunu işsizliğe ya da kalan işler için şiddetli rekabete sokacak ya da geçmişte olduğu gibi, üretilen yeni işler otomasyonla yerlerinden edilen işçileri, tolere edecektir. $\mathrm{Bu}$ sıcak tartışmalı sorular ise devlet-istihdam üzerine inşa edilmiş olan Keynesyen refah devletinin hak ve menfaatlerin kalesi olduğu dönemin geride kalması anlamına gelebilir (Estlund, 2018: 254).

Nitekim Dünya Bankası Çalışmanın Değişen Doğası isimli 2019 kalkınma raporunda, çalışma kavramının doğasının neden değiştiğini üç şekilde açıklar. İlk olarak, geleneksel üretimden dijital pazar platformları ile yeni bir üretimtüketim ağına geçiş olmuştur. Böylece küresel platform tabanlı işletmeler, dünyada internet kullanımının artması ile dünyanın neresinde olursa olsun her tüketiciye kolayca ulaşabilmektedir. Platform şirketleri müşterileri, üreticileri ve tedarikçileri birbirine bağlayan ve çok taraflı bir modelde etkileşimleri kolaylaştıran bir ağ etkisi yaratarak genellikle değer üretmektedirler. Küresel tüketimin itici gücü haline gelen küresel platform şirketleri yerel şirketlerle karşılaştırıldığında veri analitiği ile tüketici taleplerine daha uyumlu, hızlı cevap verebilirken, daha düşük maliyetle ölçeklenir. İkinci olarak, teknoloji, iş için gereken becerileri yeniden şekillendirmektedir. Teknoloji 
nedeniyle yeri doldurulabilir orta düzey beceri talebi azalmaktadır. Aynı zamanda ileri bilişsel ve sosyodavranışsal beceriler ile daha fazla ve hızlı adaptasyon yeteneğine bağlı becerilere olan talep artmaktadır. Üçüncü olarak, robotların işçilerin işini elinden alması ideali, çok sinir bozucudur. Bununla birlikte, teknolojiden gelen işlere yönelik tehdit abartılıdır ve tarih bu dersi tekrar tekrar öğretmiştir. Küresel endüstriyel işlere ilişkin veriler bu endişeleri taşımamaktadır. Gelişmiş ekonomiler sanayi işlerini diğer alanlara kaydırırken, Doğu Asya'daki sanayi sektörünün yükselişi bu kaybı telafi etmekten daha fazlasını yapmaktadır (World Development Report, 2019: 5-6).

Son yirmi yılda birçok yüksek gelirli ekonomide sanayi istihdamındaki düşüş, iyi çalışılmış bir eğilimdir. Portekiz, Singapur ve İspanya, toplam istihdam içinde sanayi istihdamının payının 1991'den bu yana yüzde 10 veya daha fazla düştüğü ülkeler arasında yer almıştır. Böylece, imalat sanayi istihdamından hizmet sektörüne geçiş söz konusu olmuştur (World Development Report, 2019: 6).

Diğer taraftan Carbonero vd. belirttiği üzere, robotlar 2005 ve 2014 yılları arasında küresel istihdamda \% 1,3 düşüşe yol açmıştır. Etki, gelişmiş ülkelerde - $\% 0.54$ ile oldukça düşükken, \% 14 ile gelişmekte olan ülkelerde çok daha belirgindir. Nitekim Carbonero vd. gelişmiş ülkelerdeki robotlașmanın gelişmekte olan ülkeler için daha ciddi bir etkisi olabileceğinin güçlü kanıtlarını bulmuşlardır. Robota dayalı üretimin, ülkeler arası ilişkilerde yeni bir dönemi başlatabileceğini ve üretimin ülke içine taşınmasına neden olabileceğini öngörmektedirler. Özetle, gelişmekte olan ülkeler için robotların istihdam üzerindeki zararlı etkisi hem küresel tedarik zincirleri yoluyla hem de ülkeler dâhilinde yoğunlaşmaktadır (Carbonero vd, 2018: 11).

Bauman, kapitalizmin ruhu Protestan ahlakının ve çalışma etiğinin yerini tüketim aldığını üretim toplumundan tüketim toplumuna geçiş sağladığını ifade etmektedir. Böylece çalışmacı toplumda, yedek istihdam ordusu yoksullar günümüzde ucuz ürün tüketicilerine dönüşmüştür. Zira kontrollü iyi tarımla üretilmiş, daha az ilaçlı daha az hormonlu yiyeceklere dahi ulaşabilme şansları azalmıştır (Bauman, 1999: 10). Bu nedenle ABD'de yoksullara yönelik olarak, kullanım süresi sonlanmış ürünlere indirim uygulanarak satılması yasaldır.

Zimmerman'a göre 'Protestan Ahlâkı ve Kapitalizmin Ruhu' isimli eseri ile tanınan Max Weber, bir sosyal Darwinist milliyetçi, 1rkçı, emperyalist biridir ve bu politik pozisyonlar sosyal bilimsel çalışmalarının temelini teşkil eder. Weber ilk olarak Almanya'da endüstriyel emek üzerine çalışma programında, genel bir ırk, etnik köken ve ekonomi teorisi geliştirmeye başladi. Zira daha kalifiye hale gelen bir sanayi işçisinin mutsuzlaştığını keşfetmiştir. Böylelikle zihinsel yeti işlevlerinden müzdarip, monoton bir çalışma talebinin kalifiye işçiler arasında sinir bozukluğu ve mutsuzluğa neden olduğunu anlamıştır. Nitekim sanayi istihdamında ekonomik verimliliği artırmak üzere, kapitalizmin emek ve etik sorununa Protestan Ahlâkı ve Kapitalizmin Ruhu isimli çalışmasıyla çözüm bulmuştur. Böylelikle çalıșanları sömürülmüşlük hissinden kurtararak, sisteme adapte edilmelerini kolaylaştırmıştır (Zimmerman, 2006: 53-57). Weber, evrensel tarih incelemeleri sonrasi "büyüsü bozulmuş dünya, akılcılık ve değerden bağımsızlık" gibi terimleri literatüre kazandırırken, Protestan Ahlâkı ve Kapitalizmin Ruhu isimli eseri bilim insanları arasında günümüze kadar gelen sıcak tartışmalara yol açar (Kaube, 2020: 12).

Öte yandan, çalışmaya yüklenen anlam değişmiştir. Zira Sanayi Devrimi sonrası bireyin çok çalışması ve kendi menfaatini en üst düzeye taşıması yönündeki Protestan ahlakı, Weber'e göre kapitalizmin yükselişinde en önemli stratejidir. Weber'e göre 'Protestan inancı sıkı çalışmanın ve değer yaratmanın önemini ve dünyevi zevklerden kaçınarak tutumlu olmanın gerekliliğini vurgulamaktadır." Nitekim bu düşüncenin, Batı toplumlarında sıkı çalışmaya dayalı bir çalışma ahlakına büyük etkisi olmuştur (Ünal, 2011: 131).

Osmanlı devletinde Batılılaşma hareketlerine baktığımızda 19.yüzyılda Tanzimat Fermanı ile hızlandığını görürüz. Avrupa'nın düşünüş ve yaşayış tarzı Türk toplumunu önemli ölçüde etkilemiştir. Tanzimat Fermanı, 1839'da okunduğunda, yarattığı atmosferin bir sonucu da Protestanların müstakil bir kiliseye kavuşmaları olmuştur (Hülagü, 2007: 430-432). 1840'lı yıllara gelindiğinde ise Amerikan misyonerleri, Osmanlı tebaası içinde yer alan gayrimüslimleri Protestanlaştırma faaliyetlerine ağırlık vermeye başlamıştır. Nitekim Avrupa değerlerinin gelişiminde kiliseler hayati bir rol oynamıştır. Protestan misyonerler, Osmanlı toprakları içinde pek çok, yetimhane, hastane ve okul yaparak faaliyet göstermiș ve sosyo-politik bazı etkiler bırakmışlardır (Karabulut, 2008: 47; Karakaş, 2010: 269-296).

Tanzimat dönemi yazarları, Osmanlı'da sosyal hayatta yaşanan değişimi gözler önüne sererler. Tanpınar (1988: 131), sosyal yaşamdaki değişimi şöyle anlatır: "Devletin garba bu şekilde kendisini açışı ile İstanbul'da hayat birden bire değișir. Beyoğlu'nda umuma açılmış Avrupakârî müesseseler, terziler, manifatura tüccarları, tuvalet eşyası ve mobilya satan dükkânlar, bilhassa Kırım harbinden sonra Müslüman halkın daha sık uğradığı yerler olur. Garp hayatının unsurları taklit ve moda sayesinde gündelik hayatımıza girerler. Devrin gazetelerinde görülen ilânlar, her gün Avrupa'dan yeni bir modanın girdiğini gösterir." Ahmet Mithat Efendi'nin Bahtiyarlık isimli eserindeki Senai karakterinin evleneceği kişide aradığı özellikler ise şöyledir: "Ancak onun sevebileceği bir kız kibarzade güzel zengin olmaktan maada okur yazar olmalı hatta Fransızca bilmeli musikiye mensubiyeti bulunmalı elhâsıl bir Avrupalı kız gibi olmalı" (Efendi, 2000: 17).

Diğer taraftan, Müslüman Sanayici ve İș Adamları derneği (MÜSİAD) ise, 1980 sonrası, İslami ekonomiyi şekillendirerek, kaynakları harekete geçirmek amacıyla kurulmuştur. Aile, İş ve Din olmak üzere üç temel değer üzerine yapılanan MÜSİAD'ın ikinci önemli değer olarak kabul ettiği iş, sebatla sürekli çalışmak anlamına gelmektedir. Tanzimat dönemi yazarlarından Nâbizâde Nazım'ın Zehra isimli romanında Zehra'nın babası Şevket Efendi 35 yaşında bir tüccardır ve bu yaşta hatırı sayılır bir servete çalışkanlığı ve ileri görüşlülüğü ile ulaşmıştır. Ancak günümüzde bir işte sıkı çalışmak ve disiplin eskisi gibi bir etki yaratmamaktadır. Tam tersine, lüks evlerde, lüks otomobillerde, lüks eşyalar ile yaşayan birey, erdemli davranış düzeyine bakılmaksızın daha saygın ve prestijli konumdadır. Bireyin sadece kendini düşünen, ötekilerini umursamayan bencil ve bireyci karakteri ile kendini gerçekleştirme arzusu toplumun altını oymaktadır. Öfke Çağı adlı kitabında Mishra, bireyin, kişisel tercih ve 
isteklerini gerçekleştirebilmesinin kendi elinde olduğu yönündeki Amerikan tarzı bireyciliğin, esasen hayata dair yapılan tüm tercihlere yansıyarak, bireyin kendi kaderini kendisinin şekillendirdiği masalına inanması ile dayanışmadan uzaklaşması anlamına geldiğini ifade etmektedir (Nazım, 2004: 28; Kabaş, 2016: 141-142; Balta, 2019: 17).

Modern dünyada, tüketici konumundaki modern vatandaş artan şekilde daha fazla kendi ihtiyaçlarını ve refahını ön plana almaktadır. Diğer taraftan geleneksel çalışma, üretim ve haz duygusu yerini tüketerek şımartılması gereken duygular ve egolara bırakmıştır. Nitekim daha az fiziksel emek harcayarak çalışan tüketici, toplumdan dişlanmaması için sahip olduğu ile yetinmek zorunda olmayan yeni bir konuma doğru sürüklenir. (Baudrillard 2004: 94).

Safiye Soyman'ın reklam filmi, "Faik, şimart beni” sloganı ile yayımlanmıştır. Film, Yemek Sepeti'nin 'bana bi' isimli cep telefonu üzerinden yüklenen ve günün her saatinde yiyecek siparişi verilebilen uygulamasının tanıtımıdır. Reklam filminde "Faik, şimart beni”" sloganı esasen, insanın kendi üst egosu ve haz duygusunu okşayacak şekilde tüketerek değerli hissetmek yargısını zihin altımıza işlemektedir (Youtube, 13.06.2020).

Oysaki Weber'e göre, dünyevi Protestan asketizmi, bilhassa lüks olan tüketimi kısıtlarken, kendiliğinden gelişen sahip olma zevkine karşı güçlü bir karşı koyma şeklinde hareket etmiştir (Weber, 1992: 115). Wallman, İstif Çağı adlı kitabında, ekonomik sistemin bireye maddiyata dayalı refahın imkanlarını sunduğunu bilakis maddeciliğin toplum refahını sağlamakta yetersiz kaldığını ifade etmektedir. Pekçok düşünürle birlikte Wallman'da tüketim kültürünün bir çeşit sahte din olduğu kanaatindedir. Zira, alışveriş terapisi işe yaramamakta, mutluluk getirmemektedir. Şöyleki ihtiyacımız olmadığı halde satın aldığımız şeyler, bir süre sonra bizi yormakta, hatta esir almaktadır. Bu geçici bir hazdır. İngiliz Filozof Jeremy Bentham'ın en sevdiği şey, sert kahve ve zencefilli kurabiyedir. Bentham, ikinci kahvenin birincisi kadar haz vermediğini fark etmiştir. Ekonomistlerin azalan marjinal fayda olarak ifade ettikleri bu durum, tüketimi azaltmamakta tam tersine, hergün mavisini mi yoksa yeşilini mi alsam diye kafa yoran insanların sayısı artmaktadır. Oysaki, felsefe hayatı yavaş yavaş kavrama bilimidir. Anlamlı sorular sorarız. Neden var oldum? Kendimi nasıl daha iyiyi doğru değiştiririm? Ünlü empresyonist Fransız ressam Monet'nin Paris'e seksen kilometre uzaklıkta Giverny'deki kır evi, günümüzde pekçok turisti ağırlamaktadır. Sekiz dönümlük bahçesi ve yapay bir gölü olan çiftlik, ressamın pekçok eserini yaptığı huzur dolu, rengarenk çiçek kokulu, doğal bir cennete benzemektedir. Mavi çiniler ile süslü mutfakta sağ tarafta kuzina vardır. Karısının yatağının başucundaki günlüğünde ise şu sözler yazılıdır:” Oğlumu bugüne kadar mağazada bir hafta sürekli gören olmadı hiç, zaten her gününü bence Louvre'da geçirmeli" (Sevindi, 30.07.2012: Hürriyet; Wallman, 2018: 67-68).

Günümüzde ise post-Fordist üretim sisteminin değiştirdiği çalışma alanı, çalışmanın değişen doğası, hayatın merkezine konan tüketim olgusu vardır. Simmel'e göre, modern dünya içinde bireyler tüketmek sureti ile var olmaktadır. Etrafimızı saran, tüketime yönelik metropoller esasen, "bütünüyle kişisel yaşam aleyhine, giderek artan şekilde bu kültürün gerçek alanını" oluşturmakta ve yapay kimlikler üreterek bireylerde 'farklı olma' arzusu tetiklemektedir. Tüketmeyi de bir farklı olma biçimi olarak gören insan, tüketerek var olmaktadır. Wallman için seri üretim ürünleri tek düze ve özgünlükten uzaktır. Nitekim bireyler, kısa bir süre sonra özgün olanı aramayı sürdürmektedir (Simmel, 2008: 149; Wallman, 2018: 68).

$\mathrm{Bu}$ çalışmada, üretimde otomasyon ve dijitalleşmenin ürettiği verimlilik nedeniyle oluşan üretim fazlasının aşırı tüketimi özendiren sürekli bir alışveriş ortamını canlı tutan yeni kapitalizm ve tüketici hakları konusunu incelemektedir. Zira, kapitalizm öncesi toplumlar da tüketim, basit insan ihtiyacını karşılamak üzere gerçekleştirilirken, günümüzde tüketim, ihtiyaç olmayan hayali ihtiyaçlar üreterek, kâr amaçlı iktisadi faaliyete ve yeni bir yaşam tarzı konumuna yükselmiştir. Teknolojinin üretime ve tüketime etkisi ile bir taraftan niteliksiz ya da yarı nitelikli emeğe ihtiyacı azalırken, diğer yandan dünyanın en ücra köşelerine bile ulaşan web ağları ile kısa sürede tüketim mallarının dağıtımına dayalı sınırsız ve kısıtsız tüketime yol açmaktadır. Borç ekonomisine dayalı tüketim, formel iş miktarının azalması ile ne kadar sürdürülebilir olabilir. Aşırı tüketim ve istif ile yok olan doğal kaynaklar ve artan çöp kuleleri içinde insan nesli nasıl yaşayabilir. Çalışmanın birinci bölümünde, tarihsel süreçte üretim, tüketim, çalışma ve kapitalizmin dönüşümleri, ikinci bölümde, bir ara uzlaşı dönemi olarak Keynesyen Refah Devleti dönemi ile sosyal hakların yükselişi üçüncü bölümde ise yeni üretim faktörü bilgi ve azalan maliyetler ile artan üretim sonrası yeni bir dönem olarak tüketim toplumu ve tüketici hakları ile tüketici güvenini incelenecektir.

\section{Kapitalizm: Üretim, Tüketim ve Çalışma İlişkisinde Yeni Dönem}

Ünlü iktisatçı Schumpeter'e göre, kapitalizm bir değişim ve gelişim sürecidir. Kapitalizmin statik olmayan niteliği, bilhassa sosyal bakımdan çok önemli bir unsurdur. Zira herhangi bir toplumu ekonomik geriliğe mahkûm eden faktörlerin arasında içe kapalı durgun yapısı ile çokluk gelmektedir. Schumpeter'e göre, kapitalist sistemi çalıştran şey; kapitalist teşebbüs tarafindan yaratılan yeni üretimulaşım metodları, yeni tüketim maddeleri, yeni pazarlar ile yeni örgütlenmelerin değişen şeklidir. Nitekim kapitalizm, statik olmadığı gibi sürekli bir ilerlemedir ve içine kapalı, çokluk olgusu (sayıca üstünlük) ile hareket eden toplumlar için uygun değildir (Schumpeter, 1966: 118). Belki de, kapitalizmin kalbindeki ilerlemeye dair en çarpıcı yorumu Walter Benjamin yapmıştır. Zira Klee'in "angelus novus" adlı bir tablosunu satın alan ünlü edebiyat eleştirmeni, bu tabloyu geçmişe dönmek ve geçmişin yıkıntılarını ve yaralarını sarmak isteyen, yüzü geçmişe çevrili meleğin, sırtını döndüğü şiddetli firtına tarafindan geleceğe sürüklendiğini ve işte bu firtınanın ise ilerleme olduğunu ifade etmiştir (Gevgili, 1972: 45; Bahçe, 2011: 176). Nitekim tarihte ilerleme kaçınılmazdır. Avrupa Bankası Eski Başkanı Jacques Attali' in Gelecek Hakkında Kısa Bir Hikâye Kitabı'nın önsözünde, “Tarih, öngörmemize ve yönlendirmemize izin veren yasalara boyun eğer" ve "Geçmişten bugüne, hiçbir sarsıntının bugüne kadar kalıcı bir biçimde yolundan çeviremediği tek olgu, bireysel özgürlüktür. İnsanlık bir yüzyıldan diğerine geçerken 
bütün öteki değerler karşısında, bireysel özgürlüğü öncelemektedir" sözleri vardır. (Attali, 2017: 5).

Attali’ye göre, tarih "bireysel özgürlük” olgusunu şu şekilde öncelemektedir: "Her türden bedensel gücün önemi azaltan teknik gelişmelerle, her türlü esaret şekline katlanmayı giderek artan şekilde dışlayarak, siyasi sistemleri, ideolojileri örfleri, gelenekleri ve sanatı liberalleştirerek" (Attali, 2017: 23). Nitekim Attali için gelecekte serbest piyasa ekonomisi içerisinde hiper demokrasi sağlamak üzere ilişkisel işletmeler ve insanaşırılar karşımıza çıkacaktır. İnsan-aşırılar, ekonomin sürdürülebilmesi için kamu kurumlarının çözemediği sorunları çözecekken, ilişkisel işletmeler ise sosyal sorumluluk taşıyan ve sadece kâr amacı gütmeyen çok yönlü kuruluşlar olacaktır (Ergun, 2007: 175).

\section{1. İngiliz Sanayi Devrimi ile Ürettiğini Satın Alamayan İşçiler}

İngiliz Sanayi Devrimi öncesi dönemde, tarımdan sonra en önemli üretim şekli olan zanaatkârlık, meşakkatli bir öğrenme süreci sonrası edinilen beceriler ile saygı duyulan ve ustalık gerektiren bir iştir. Sennett'e göre zanaatkârlık uzun bir öğrenme süreci ile maddi olmaktan çok manevi olarak, bilişsel ve zihinsel bir süreç sonrası ustalık gerektiren bir işi iyi yapmak üzere bireyin kendisini o işe adaması halidir (Sennett, 2013: 53). Ancak, sanayi devrimi, çalışma ve çalışma ilişkilerinde yeni bir dönemi başlatmıştır. Makineli üretime geçiş ile birlikte; zanaat üretimi, giderek azalmış ve günümüzde yok denecek seviyeye ulaşmıştır. Nitekim insanlığın doğadan koparılarak kapalı bir ortama hapsolduğu yeni dönem, fabrika adında yeni bir çalışma düzenini getirmiştir. Fabrika, atölyelerin yerini alıp işi parçalara bölerek, çalışanların üretim sürecine olan hakimiyetini sınırlayan büyük üretim mekânları olarak karşımıza çıkmıştır. Oysaki zanaatkârlık, küçük atölyelerde gerçekleştirilen üretimde el emeğinin hâkim olduğu ve üretim araçlarının mülkiyetinin zanaatkârlara ait olduğu, yüksek beceri gerektiren bir meslekti ve tüm üretim süreci zanaatkârın kontrolü altında gerçekleşiyordu (Doğan, 2012: 67-70). 19.yüzyılın sonlarına doğru tüketim mallarını üreten işçiler, maalesef ürettikleri ürünleri satın alma gücüne sahip değillerdi ve kazançlarının yarıdan fazlası yeme-içme ihtiyacına gidiyordu. 18. Yüzyılda ise durum daha da kötüleşir. Ünlü Fransız yazar Zola'nın Germinal isimli kitabı, Fransız Devrimi öncesi, maden işçilerinin fakru zaruret içindeki yaşamlarını anlatır. Eserde, çok çalıştıkları halde kazançları yeterli beslenmelerine yetmeyen maden işçileri ile ailelerinin durumu anlatılmaktadır. Kadın otuz dokuz yaşında olmasına karşın doğurduğu yedi çocuktan sonra bozulan, kaba, hantal bir güzelliğe sahip, işe gitmeye hazırlanan erkeği giyinirken ağır ağır konuşuyordu: "Hey buraya bak, bende metelik kalmadı, üstelik bugün Pazartesi ve yevmiye almamıza altı gün var daha. Bunun böyle sürüp gitmesi imkânsız bir şey, hepiniz birden (5 kişi) toplam 9 frank getiriyorsunuz. Adam yere eğilmiş kayışını ararken cevap verir: "Yakınmaya hiç gerek yok hatun, sapasağlam adamım. Kırk iki yaşında ıskartaya çıkan nice erkek var." Kadın ise şöyle cevap verir: "Bu bizim karnımızı doyurmuyor ki” (Zola, 2003: 21). İşçiler arasındaki örgütlü mücadeleler ve komünizm akımının yaygınlaşması ile her yanı saran devrim ruhu, nihayetinde 20.yüzyılda bir değişime neden olur ve sosyal haklar, hak öznesi işçiler ile mevzuatta yer almaya başlar. Nitekim 1914 y1lında Amerikalı mühendis Henry Ford, Taylor'1n bilimsel yönetim yaklaşımını kullanarak, montaj hattını otomobil fabrikasına uyarlamış ve Model $\mathrm{T}$ isimli otomobili seri üretime geçirmiştir. Aynı zamanda ilerici bir mühendis ve iş adamı olan ve dünya barışını destekleyen Ford, seri üretime geçen otomobili üreten işçilerin satın alabilmesi için ücretlerine zam yapmış ve kitle üretimini kitle tüketimi ile destekleme yolunda önemli bir adım atmıştır (Şan ve Hira, 2004: 2; Çelik ve Küçük, 2020: 6).

20. yüzyılın sonlarına doğru gelişme gösteren post-Fordist üretim sistemi, endüstriyel robotlar, bilgisayarlaşma ve otomasyon ile niteliksiz yarı nitelikli işgücüne talebin azalmasına neden olmaya başlamıştır. Zira post-Fordist üretim sistemi, yeni bir tüketim anlayışına neden olarak kapitalizmin yeniden inşasına yol açmıştır. Böylece, üretim süreçlerinde meydana gelen dramatik değişiklikler, üretim toplumundan tüketim toplumuna bir geçişi sağlamaktadır. Alışveriş alışkanlıkları bile değişen yeni toplum, dijital sosyal platformların ve bağımlılığın esiri olmaktadır (Çelik ve Küçük, 2020: 2). Esin'e göre, sanayi devrimi, bir çalışma disiplini içerisinde, insan emeğini metalaştırırken fabrika ortamını düzenleyen ve denetleyenler ile emeğini satanları bir araya getiren bir toplumsal düzen inşa etmiştir. Nitekim üretim ya da çalışma bir insanın bir tarafi iken diğer tarafi ise tüketimdir. Zira Esin'e göre endüstri çağının, giderek artan oranda, daha bağımlı ve otomatikleşen bir gerçeğidir, tüketim. Ancak tüketicinin pazarda serbestçe seçme ve yeğleme hakkı var gözükür iken, bilinçaltına yerleştirilen imgelerle mutluluğun ana kaynağı şeklinde gösterilen tüketim ile tıpkı işçi nasıl çalışma makinesine dönüştürülmüşse, tüketici de otomatik bir tüketim mekanizmasına dönüşmektedir. Ancak sistem tarafindan yönlendiren tüketim arzusu, özgürlüğü ve iç huzuru sağlamamaktadır (Esin, 1982: 7).

\subsection{Yeni Üretim Teknolojileri ile Değişen Çalışma Kavramı ve Dijital Tüketim}

Soyut bilim, dolaylı şekilde insan gelişimini kontrol eder. Öyle ki, birkaç yıl gecikmeyle teknolojiyi tetikler ve yaşam tarzına nüfuz ederken uluslararası ilişkiler ile siyasal davranışları etkiler. Teknolojik ilerleme, tarım ve yerel hizmetler ile meslekler aleyhine, randımanlı sanayilerin gelişimini de sağlamaktadır. Nitekim bir Amerikan vatandaşı mütevazı yollardan bir otomobil ve bir televizyon setine sahip olsa da, bir hizmetçi çalıştırmaya maddi gücü yetmez. Aynı seviyede ücretli çalışan bir mısırlı işçi ise bir TV setini bile alamaz. Bilim ve teknoloji, tüketim mallarının çoğalmasını ve daha az ücretle satın alınmasını kolaylaştırır ancak, ne gerçek anlamda firsat eşitliği sağlar, ne de özgürleştirir. Diğer taraftan, yetersiz tüketim ile yerel seviyede kalan bilginin hâkim olduğu prekapitalist bir yaşam tarzı medeniyetinin büyümesinin ileri bir gelişimine izin verir (Moch, 1956: 112).

2019 Dünya Kalkınma Raporu'nda Karl Marx'dan bir alıntı vardır. "Makineler, çalışanlara karşı üstün bir rakip iken, öte yandan onları daima boşa çıkarabilecek durumdadır. Bu ise makinelerin grevleri bastırmak için en güçlü silah olmasını sağlamaktadır" (World Development Report, 2019: 2).

Nitekim Marx, teknolojik gelişmenin sınıf mücadelesini olumsuz etkilediğini düşünmektedir. Marx'a göre, işverenin 
teknolojiye yatırım yapmasının sebebi grevleri kırmak ve emek piyasasını kontrol etmek isteğidir. Klasik yönetim yaklaşımı öncülerinden bilimsel yönetim yaklaşımı kurucusu Taylor'ın ürettiği ve montaj hattının oluşumuna zemin hazırlayan Taylorizm hakkında Harvey, işçiyi eğitimli goril haline sokmaya çalışan sistem demektedir. Nitekim Marx'ın ifade ettiği gibi teknolojiyi yeniden üreten fabrika ortamı, eski teknolojileri söküp atarken yenilerini tekrar üretmekte ve kapitalizmi yeniden şekillendirirken üretim ile desteklemektedir. Toplumun alt yapısını üretim, üretici güçler ve üretim ilişkilerinin oluşturduğunu söyleyen Marx, sömürücü üretim ilişkilerinin sınıf mücadelesine yol açtığını ve eninde sonunda bu çelişkinin proletarya devrimine neden olacağını iddia etmiştir. Aynı zamanda üretimde hızlı teknolojik gelişmelerin, üretim hadlerinde yükselișe ve üretim fazlasına neden olacağ $\breve{y}_{1}$ için sistemi krize sokacağını da savunmuştur. Nitekim günümüzde gelişmiş ülkelerin üretimde kullandığı endüstriyel robotlar, üretimde verimliliği sağlarken, imalat sanayi istihdamını olumsuz etkilemektedir. Ancak, üretim fazlasına neden olup, sistemi krize soktuklarını iddia etmek mümkün gözükmemektedir. Zira aşırı tüketime dayalı yeni kapitalizm sistemi krize sokabilecek bir üretim fazlasını emmektedir. Öncelikle, endüstriyel robotlar, otomasyon ve djitalleşme gibi hızlı teknolojik gelişmeler, üretimde verimliliğe ve kaliteye neden olurken, bilakis bazı ürünlerin maliyetleri, istenen düzeye düşmemektedir. Keza, ABD'de yükselen teknoloji ile imalat sanayii istihdam oranları düşerken, diğer yandan Çin emek yoğun imalat sanayisi ile daha ucuza üretebilmektedir. İkincil olarak, üretimde sürekli inovasyonun, yeni bir ürünün uzun bir süre piyasada kalmasını engellemesidir. Zira yeni bir ürün bir pazarı doygunluğa ulaştırmadan, rakip firma tarafindan hızlı şekilde taklit edilerek, benzer özelliklerde başka bir ürün piyasaya sürülmektedir. Diğer yandan modası sürekli değișen ürünler ile ihtiyacı olmayanı almaya yöneltilmiş tüketim toplumu, üretim fazlasını emmektedir (Duman, 2016: 21; Çınar, 2018: 3-4).

Zira kullanım oranı hızla artan endüstriyel robotlar, yapay zekâlı bilgisayarlar, emeğin yerine tercih edilmekte ve üretimde verimliliği artırmaktadır ancak dünya henüz maliyetlerin düşürülmesi yönünde istenen noktada değildir. $\mathrm{Bu}$ ise, inovasyon ve ar-ge yatırımlarına her gün daha fazla para yatıran şirketleri karşımıza çıkarır. Schumpeter'e göre, kapitalizmin doğasında değişim vardır ve teknolojik ilerleme ise kapitalist ekonomik gelişmenin motorudur. Kapitalizm sürekli bir ilerleme olduğu için tıpkı Klee'nin Angelus Novus tablosunda resmettiği gibi geçmişe ve geçmişin yıkıntılarına dönmeyi mümkün kılmazken, sürekli bir yaratıcı yıkım ile insanlığın sosyo-ekonomik gelişimini şekillendirmektedir. Diğer yandan yeniliklerin yayılması (diffusion), Marx'ın teknolojik gelişmenin üretim fazlasına ve krize sebep olacağı tezini zayıflatmaktadır. Zira günümüzde yenilik iktisadi ürünün yaşam süresini azaltmıştır. Böylece, ne kadar yeni olursa olsun bir ürün pazara nüfuz edemeden rakip firmaların benzerini ya da daha ilerisini üretmesiyle satış oranları düşebilmektedir. Nitekim günümüzde hiçbir ürün üretim fazlası oluşturacak şekilde uzun dönemde piyasaya sürülemez zira eksik tüketim ile karşılaşma riski vardır. Diğer yandan dünyanın en tanınan perakende zinciri ABD'li Wallmart gibi şirketler günümüz teknolojisi ile maliyeti iyiden iyiye düşürülen bazı ürünleri çeşitli indirimler (promosyon, kupon...) ve daha fazla satın alın, tasarruf edersiniz şeklindeki sloganlar ile satabilmektedir. Henüz endüstriyel robotlar kendi değerinin üzerinde değer üretemese de emeğe rakip olmakta ve postfordist sistemin getirdiği esneklik ve devletin küçülmesi şeklindeki neoliberal politikalar beraberinde emeğin değerinin düşmesine ve işgücü satın alma gücünde azalmaya neden olmaktadır. Böylece üretim değeri hızla düşen işgücü ile istihdam oranlarındaki azalma ve işsizlik gibi faktörler, aynı zamanda çalışanların satın alma gücünü olumsuz etkilemektedir (Aydın ve Araman, 2018: 45; Miller ve Atkinson, 2019).

İmalat Sanayi istihdamı başta olmak üzere ciddi istihdam daralmalarına neden olan yapay zekâlı yazılımlar ile bilgisayarlaşma, finansal aracılık yapan şirketleri de olumsuz etkilemektedir. Eskiden, bankalarda ya da çeşitli finansal aracı şirketlerde çalışan ve iyi bir maaş sahibi olan brokerler günümüzde hizmet sektöründe yaşanan hızlı teknolojik gelişmeler nedeniyle istihdam kayıpları ile karşı karşıya kalmaktadır. Değişen müşteri talepleri ve teknolojik gelişmeler gerekçe gösterilerek, işten çıkarılan banka çalışanı sayısı her yıl daha da artmaktadır. İtalya'nın tanınmış uluslararası ticari bankası UniCredit, üç yıl içinde Almanya ve Avusturya'da küçülmeye gideceğini ve 500 kadar şubesini kapatarak, sekiz bin çalışanını işten çıkarmayı planladığını 2019 yılında duyurmuştur. Benzer şekilde, İngiliz Lloyds 2016 yılında küçülmeye gideceğini ve 2017 yılı sonuna kadar 200 şubesini kapatacağını ve 3 bin kişiyi ise işten çıkaracağını ilan etmiştir (NTV Ekonomi Haberleri, 27.07.2016; NTV Ekonomi Haberleri, 03.12.2019; Sözcü, 20.11.2019).

Tüm bu gelişmeler, sanayileşme ile elde edilen kazanımların sanayi ötesi toplumda sürdürülüp sürdürülemeyeceğini şüphesini karşımıza çıkarır. Zira kalkınma sadece sanayinin kurulması ve gelişimi değildir. Feodal düzenin sonlanması, modern düşüncenin gelişimi, hukuk, eşitlik, kadın hakları, eğitim, demokrasi ve sosyal adalet ile çağdaş ve özgür toplumun oluşturulmasıdır. Ancak, sanayi ötesi toplumda, Foucault'un söylemiyle gerçek bir özgürlük söz konusu değildir. Piyasa değerlerinin hâkim olduğu, çıkar ve rekabetin kontrolünde gerçekleşen neo-liberal yönetimsellik sisteminde, haklar ve yasalar değil, piyasa ilişkileri üzerinden denetimli bir özgürlük söz konusudur. Nitekim eğitim, sağlık, sosyal güvenlik gibi sosyal haklar piyasaya açılırken, diğer yandan, buluş ve icatları üretim sistemi içinde uygulayan girişimciler, emeğin üretkenliğini artırırken bilakis acımasız rekabetin içine atarak, insanoğlunu sürekli kendini yenilemek durumunda kalan bir makineye dönüştürmektedir. Böylece, eğitimine ve becerilerini geliştirmeye sürekli yatırım yapan birey, acımasız rekabet koşullarında dinamik, hızlı adapte olan ve esnek bir üretim aracına dönüşmektedir. Öte yandan, yeterli maddi imkânları olmadığından kendi kendine yatırım yapamayan bireylerin ise, sürekli alım güçleri azalmakta ve sefalete mahkûm olmaktadırlar (Soylu, 2015: 123-124; Brown, 2018: 137).

\section{Keynesyen İktisat Politikaları ve Sosyal Hakların Yükselişi}

Sosyal demokrasi, sosyalist ekonomi ile demokrasi ve liberal özgürlüklerin bir bileşimidir. Sosyal demokrasi, refah devleti olarak bilinmektedir. İngiliz İktisatçı Keynes, 'Refah Devletinin,' uygulayıcı babasıdır. Keynes, serbest 
piyasa ekonomisinin, doğası gereği istikrarsız olduğunu zira ticaretle uğraşanların kısa vadeli menfaatleri nedeniyle, dönem dönem ekonomik krizler ile durgunluklara yol açacağından, ekonomik iyileştirmenin ise sadece devlet müdahalesi ile yapılabileceğini iddia etmiştir. Birleşmiş Milletlerin kurulduğu 1945 yılında, Keynes'in devlet müdahalelerini öngören Keynesyen ekonomik modeli (sosyal refah devleti modeli), etkisinin zirvesindedir. Birleşmiş Milletler'in 1948'de kabul ettiği “İnsan Hakları Evrensel Beyannamesi," sadece liberal sivil ve politik hakları değil ayrıca ekonomik ve sosyal hakları da içermektedir. Beyanname'nin 25. maddesi, "herkesin yeme, giyinme, barınma, tıbbi tedavi ve gerekli toplumsal hizmetler dâhil sağlık ve refah için yeterli yaşam standardına sahip olma hakkı olduğunu ve işsizlik, hastalık, engellilik, dulluk, yaşlılık durumunda veya bireyin kontrolünün dışındaki diğer geçim mahrumiyeti koşullarında güvenlik hakkı olduğunu" belirtir. "İnsan Hakları Evrensel Beyannamesi," liberal politika ile devlet yükümlülükleri olarak Keynesyen sosyal demokrat iktisadı, uluslararası hukukun altında birleştirir (Güllüpınar, 2012: 95-96; Freeman, 2016: 170-171).

\subsection{Fordist Üretim Sistemi: Kitle Tüketimi ve Sosyal Haklar}

20. Yüzyıl kapitalizmi, çekirdeğinde "Fordist sermaye birikimi rejimi" ile yükselen vatandaşlık ve sosyalekonomik haklar beraberinde, kamu alanındaki tekelci (devlet) anlayışı ile kamu ekonomisinin boyutlarını genişletmiş, refah devleti ve sosyal politikaları yaygınlaştırmıştır. Laissez Faire politikalarının geçerli olduğu bir önceki döneme kıyasla devletin ekonomik ve sosyal alandaki etkinliği giderek artmıştır. Devlet, ekonomik alanın tüm birimlerine müdahale etmiş, altyapı yatırımlarını üstlenmiş, emek piyasalarına ve endüstriyel ilişkilere müdahale ederken, sadece kamu hizmeti değil ticari mal üretimini de yürütmüştür. Bu bağlamda devletin sosyal, ekonomik ve kültürel düzeylerde müdahalesi ile özel sermayenin neden olduğu birtakım sorunları çözme yönünde ekonomiyi planlama ve örgütleme çalışması söz konusudur. Nitekim devlet, vatandaşını sermaye sınıfinın sömürüsünden korumakla mükellef olmuştur (Güllüpınar, 2012: 96-97; Sönmez, 2016: 43).

Birinci Dünya Savaşı sonrasında yaygınlaşan Fordizm, 1970'li yıllara kadar kapitalizme damgasını vurarak, sadece kitlesel üretim değil, aynı zamanda kitlesel tüketimi (toplam talebi) de teşvik etmiştir. Toplu üretim sürekli genişleyerek yeni yatırımları gerektirmiş, zira yeni yatırımlar emek verimliliğini artırırken, üretilen malların göreli fiyatlarının düşmesine ve malların daha geniş toplumlar tarafindan tüketilmesi imkânını doğurmuştur. Nitekim Fordist üretim politikasının istikrarı için toplu tüketime ihtiyaç oluşmuş böylece çalışanların önemi artarken "sosyal sınıfların zenginlikten pay almasının bir yolu olarak, refah devletinin oluşumuna zemin hazırlamıştır. Bu ekonomik ve sosyal yapının endüstri ilişkileri alanına yansıması ise, demokrasi sendikal özgürlükler ve sosyal haklar temelinde bir uzlaşma şeklinde olmuştur." Ancak, dünya geneline yayılan toplumsal uzlaşı sistemi, 1970'lerin sonlarına doğru yeni bir üretim sistemi olan post-Fordizm ile bozulmuştur (Erdoğdu ve Kutlu, 2014: 63-114).

\subsection{Post-Fordist Üretim Sistemi ve Değişen Değerler}

Müzik, film ve televizyon programlarını tüketmek, restoran ve otel seçmek, moda ürünleri satın almak, reality şovları gözden geçirmek üzere kişiselleştirilmiş öneriler ve sosyal medya platformlarını kullanırız. Kısacası, teknolojik cihazları kullanarak tüm tüketim olanaklarına erişebiliyor, dünyayı izleyebiliyoruz. Sosyal medyada yazılım işlevleri, veri işlemleri ve bilgi siparişi teknikleri, tüketim mallarına, sosyal faaliyetlere ve kültürel süreçlere yeni ve önemsiz yollarla aracılık eden yeni bir teknolojik rejim oluşturur (Alaimo, 2014: 9).

Andrejevic'e göre, insanları dijital gözetim mekanizmaları aracılığı ile gözetim ve denetim altında tutarak, tüketici davranışlarını kontrol eden kapitalizm, kendini yeniden yapılandırmaktadır. Son yıllarda işletmeler yeni ürün geliştirme potansiyellerini, tüketici davranışlarının tahmin edilmesi üzerine veri madenciliği kullanarak gerçekleştirmektedir (Akdağ, 2015: 78).

Aynı zamanda, dijital teknolojilerdeki gelişmelere bağlı olarak vatandaşlık hak ve sorumluluklarıyla ilgili yeni durumlar (dijital vatandaşlık, e-Devlet, sanal ticaret, sosyal medya, sosyal ağlar, vb...) ve birtakım sorunlar (dijital bölünmüşlük, kimlik hırsızlığı, kişisel bilginin gizliliği, siber dolandırıcılık, siber zorbalık vb-) ortaya çıkmıştır (Yaylak, 2017).

Oysaki sosyal vatandaşlık kavramı, refah devleti anlayışı ile yakından bağlantılıdır. $\mathrm{Bu}$ nedenle, kazanılan hakların piyasa güçleriyle uzlaşmasını kolaylaştırdığı için sosyal vatandaşlık çoğulculuk ve kapitalizmle yakından ilişkilidir. 'Sosyal vatandaşlik' teriminin kökeni, sosyal eşitsizliğin, siyasi hak ve özgürlüklerin tam olarak gerçekleşmesinin önünde bir tehdit olduğunu gören T. H. Marshall'a kadar geriye gitmektedir. Zaman içerisinde, siyasal haklardan, medeni haklara ve oradan sosyal haklara doğru, üç yönlü vatandaşlık hakları çerçevesinde modern devletten sosyal devlete bir genişleme gerçekleşir. Böylece, tüm dünyada sendikal faaliyetlerin güçlenmesi, işçi partisinin iktidara gelmesi gibi sosyal grupların siyasi yükümlülüklerini artıran gelişmeler emek piyasalarına çalışan lehine müdahaleyi güçlendirmiştir (Stambolieva, 2015: 379-394).

1970'li yıllarda kamu politikalarının sosyal bileşeni, sosyalizmin başarısızlığı ile ilişkilendirildi ve geniş çaplı sorgulanmaya başlandı (Stambolieva, 2015: 379). Bilindiği üzere, 20.yüzyıl, sosyal devletin evrensel anlamda yasal zeminini oluştuğu ve ulusal ekonomilerin planlama ile bütünleştiği bir dönemdir. Bilhassa, "Planlama”, “20. yüzyılda dünyaya hâkim kapitalist sistemin temelini oluşturan -ve iktisatçılarca doğal ve evrensel olduğu iddia edilen- piyasa ekonomisine bir müdahale aracı olarak ortaya çıkmıştır” (Yılmaz, 2012: 182). Bretton Woods sistemini kuran ABD, Dünya Bankası ve IMF için "Dünyada huzurun tesisini sağlamak üzere kurulan uluslararası kuruluşlar, azgelişmiş ülkelerin gelişmelerine destek olmaktadır" şeklinde ifade ettiği dış politikası ile maddi yardımda bulunulan ülkeler üzerinde serbest piyasa yanlısı ekonomik baskısının temelini yapılandırmıştır (Y1lmaz, 2012: 181-182).

İkinci Dünya Savaşı sonrası dönemde pek çok ulus devlet tarafindan yürürlüğe konulmuş olan sosyal devlet uygulamaları esasen, 1917 Ekim Devriminin kapitalist 
dünyada yarattığı endişe beraberinde Fordist imalat üretim sürecindeki yarı vasıflı milyonlarca çalışanın çetin mücadelesi sonrası, montaj hattına dayalı sanayi 2.0 ile artan istihdam, satın alma gücü ve tüketim çerçevesinde sermayenin iç piyasa gereksinimini karşılamaya yöneliktir. Merkez ülkeler, Fordist imalat üretimi ile yüksek üretim ve sanayileşme hızına sahip olurken, çevre ülkelerin ithal ikameci politikalar uygulamalarına izin vermiştir. 1970'li yıllarda daralan kâr hadleri, merkez ülkelerin birikim krizi ile karşı karşıya kalmasına neden olmuştur. Aynı zamanda 1950'li yıllarda Londra'da, ağır metallere dayalı üretimin neden olduğu büyük sis, asit yağmurları, hava kirliliği pek çok insanın ölümüne yol açarken, diğer yandan yeni bir politikanın üretimini sağlamıştır. Bundan böyle, merkez ülkeler, ucuz işgücüne, hammadde kaynaklarına rahatça ulaşırken, neden olduğu çevre kirliliğinden mesul tutulmayacakları tam bir özgürlük içinde olacakları sermayenin serbestçe hareket edeceği yeni bir sömürge politikasına yön vermişlerdir. Çok uluslu şirketlerin özgür bir şekilde dışarıya açıldığı ve ulus devletlerin kamulaştırma dâhil sinırlandırıldığı bu dönem neoliberalizm olarak adlandırılmıştır. Aslında özgürlük sermaye için tarihin her döneminde vardır. Ancak, bazı bilim insanları çok uluslu şirketlerin çevre ülkelerin hammadde kaynaklarını sömürdüğünü iddia ederken, diğer bilim insanları ise, çok uluslu şirketleri "topyekûn ve dengeli gelişmenin, eğitimde firsat eşitliğinin, geniş kapsamlı bir güvenlik sistemi içinde silahsızlanmanın" esasen, dünya barışının bir aracı şeklinde görmektedirler (Kutal, 2000: 71; Gerçil, 2004: 147).

Fordizm yarı vasıflı emeğin istihdamında önemli bir rol oynarken, post-Fordizm programlanabilir makineler, enformasyon teknolojisi, yenilik ve üretim sisteminde sürekli verimliliği ön plana çıkarmıştır. Post-Fordist üretim sistemine geçiş, çok uluslu şirketlerin gelirlerinde artışa neden oldu. Bilhassa otomobil üretiminde endüstriyel robotların kullanımı büyük bir verimlilik artışına neden olurken diğer taraftan her bütçeye uygun otomobil satışları mümkün olmuştur. Tüm bu gelişmeler yarı vasıflı ve vasıfsız emeğe olan ihtiyacı azaltırken, bilgisayarların, yapay zekâların insanın yerine geçebileceği ve makinelerin de kendi değerlerinin üzerinde değer üretebileceği savını karşımıza çıkarır. Yakın geçmişte piyasaya hakim olan cep telefonu üreticilerinden, Nokia başta olmak üzere Motorola ve Blackberry inovasyon ile tüketici taleplerine yeterince önem vermediğinden bugün piyasadan silinmişlerdir. Bu üç firmanın da düştüğü hata, değişime ayak uydurmamak ve atalete yenik düşmektir. Oysaki, günümüzde kıran kırana rekabet eden Huawei, Apple ve Samsung'u birleştiren en temel özellik ise Ar-ge departmanlarına verdikleri önemdir. Bilhassa, akıllı telefon satışlarında dünya genelinde düşüş yaşanırken, 2019 yılının ilk çeyreğinde Apple'ın iPhone satışları \%32 düşer ve Huawei satışlarını \%50 artar. Diğer bir husus ise uluslararası akıllı telefon pazarının en büyük on üretici firmasının yedisinin Çinli oluşudur (Habertürk, 09.05.2019; CNN Türk, 24.09.2013). Zira, 1978'de serbest piyasa ekonomisine geçiş yapan Çin büyük bir kalkınma ivmesi yakalarken, 2012 yılından beri, ABD'li sosyal medya şirketlerine karşı sert bir tutum almıştır. Bir taraftan Trump, Huawei ve Tik Tok firmalarını, Çin Komünist Partisi ile ilişki kurmakla suçlarken, diğer yandan Çin iddiaları yalanlamış ve ABD'yi Çin'in teknolojik yükselişini engellemeye çalışmakla suçlamıştır. Nitekim teknoloji milliyetçiliği tüm dünyada yayılmaya ve tüketici vatandaşlığı kavramı gelişmeye başlamıştır. 2019 yılının sonuna doğru yeni fabrikasında saniyede bir tane akıllı telefon üretebileceğini ilan eden Çinli Xiaomi, üretimde verimliliğin geldiği son noktayı vurgulamaktadır (Kalelioğlu, 2019 ; Zorlu, 02.09.2020). Çin akıllı telefon piyasasında elde ettiği bu başarıyı sadece, inovasyon ve yüksek teknoloji kullanımına bağlı olarak değil, aynı zamanda maliyeti düşük üretim ile sağlamaktadır. Bu durum Samsung, Apple gibi firmalar yanı sıra ticaret savaşlarını bir tarafa atan Elon Musk'ın Çin'in Şangay bölgesinde Çin tüketicisinin zevklerine özel yeni bir elektrikli otomobil üretimi işine girmesini sağlamıştır (Sözcü, 16.01.2020).

Günümüz sanayi sonrası devletinin aksine Keynesyen refah devletinin en baştaki ehemmiyeti sosyal mahrumiyetin hafifletilmesi endişesinin altında yatan esas temanın toplumu daha yüksek bir etik zemine taşıması olmuştur. Sosyal güvenlik ve refah devleti daha derin bir toplum ile karşılıklı yükümlülükleri kurumsallaştırarak toplumu ileriye götürmüş̧ür. 1950'li yıllarda Uluslararası Evrensel İnsan Hakları Beyannamesi ile insan hakları kavramı, uluslararası topluma taşınırken, vatandaşlarına uygun sağlık ve refah hizmetleri sağlama fikri uluslararası arena da genel kabul görür hale gelmiştir. Sosyal vatandaşlığın yükseldiği bu dönemin kısa ömürlü olmasının belki de en önemli nedeni, icat, yenilik ve buluşun üretim teknolojisine uygulanması sonrası programlanabilir makinelerin üretim verimliliğini artırarak, insanı geride bırakması olmuştur. Keza, tanınmış mobilya üreticisi IKEA, Çinli dijital platform sitesi sahibi AliBaba'nın kısa sürede sağladığı yüksek kâra uzun yıllardan beri ulaşamamıştır. Bu da, değerin sadece emek üzerinden üretilmediği yeni bir dönemin kapılarını açmaktadır ve ulus devletleri tehdit etmektedir. İş ve gelir güvencesi azalan çalışan, vergisini ödediği ve tüketime katılabildiği ölçüde değerlidir ve sosyal vatandaşlıktan küresel vatandaşlığa doğru yeni bir döneme adım atılmıştır (Estes ve Phillipson, 2002: 5-6).

\section{4. Üretime Dayalı İktisadi Kalkınmadan Tüketime Dayalı Ekonomik Büyümeye: Tüketici Hakları ve Tüketici Güveni}

Varlığı tüketime bağlı olan, kapitalist üretim sistemi, iktisat literatürüne sonsuz ihtiyaçlar kavramı ile girer. 1929 Dünya Ekonomik Bunalımı ile bir süre dışa kapalı ekonomiler ile yönetilen dünya, İkinci Dünya Savaşı sürerken ABD önderliğinde varılan Bretton Woods uzlaşısı ile kısıtsız serbest ticaret politikaları ve dışa açık yeni bir uluslararası ekonomik sistemi kurulur. Bretton Woods konferansinda White ve Keynes'in çalışmaları önplana çıkar. İngiliz iktisatçı Keynes'e göre, sermaye hareketlerinin kontrolü, uluslararası finans sisteminin işleyişi için gereklidir bilakis Amerikalı White ise uluslararası sermaye kontrolünü 'akıl kontrolü' olarak görmektedir (Türkcan, 1980: 75; Yılmaz, 2009: 1-14; Uçkaç, 2010: 422). Boratav'a göre, Bretton Woods Konferansı ile kurulan ekonomik sistemin, sermaye hareketlerinin denetlenmesini öngören bir niteliği varken, 1980'lerde uygulamaya konan neoliberal politikalar ise, Sınırsız piyasacı ve açılmacı bir iktisat doktrini ile ekonomiye egemen olmuştur (Boratav, 2019: 312). Bretton Woods ile ABD, merkezi ABD'de olan ve yönetimlerini etkin şekilde kontrol ettiği uluslararası kuruluşlar 
vasıtasıyla az gelişmiş (bugün yükselen piyasalar) ülkelerin iç ve dış politikalarını etkileme gücüne sahip olmuştur. Nitekim doların "rezerv para" olması ile elde ettiği üstünlük sayesinde, ABD, kritik üretim faktörlerini kontrol edebilme yeteneğine sahip olmuştur (Bakırtaş ve Haydaroğlu, 2015: 285).

İkinci Dünya Savaşı sonrası, tüm dünyada hâkim olan Keynesyen ekonomi anlayışı, esasen toplumsal refahın oluşmasında, kamu menfaatine ve tam istihdam düzeyine ulaşarak, üretim ve tüketim arasındaki dengenin sağlandığı bir sistemi ifade etmektedir. Böylece kalkınmanın başat aktörü gerek gelişmiş gerekse gelişmekte olan ülkelerde devlet olurken, kalkınma demokrasinin olmazsa olmazı olmuştur. Keynesyen ekonomi, 1970'lerdeki petrol krizi ve 1973 Bretton Woods sisteminin sonlanması ile gündemden düşmüştür. Böylece, yeni liberal görüşün öncüleri olan Friedman ve Hayek'in önerdiği devletin piyasalara müdahale etmediği ve üretimde kamu iktisadi kuruluşlarının yer almadığı bir serbest piyasa düzeni getirilmiştir. Böylece, başta Dünya Bankası olmak üzere pek çok uluslararası kuruluşun raporlarına yönetişim kelimesi girerken, gelişmekte olan, az gelirli ülkelerde devlet, merkezi konumdan düzenleyici konuma gerilemiştir (Sakl1, 2013: 107-110; Aslan, 2015: 1-5).

Nitekim planlamanın ve refah devletinin hâkim olduğu iktisadi kalkınma döneminden, neoliberal politikalar beraberinde planlama işlevi önemsizleşirken, devlet eliyle düzenlenen ekonomiden, düzenlenmemiş yeni bir kapitalist ekonomiye geçiş söz konusu olmuştur. Nitekim 1990'larda, Dünya Bankası'nın gündemine yönetişim kavramı girmiştir. Yönetişim ile devlet, yönetim erkini gerçekleştirirken sendikalar, sivil toplum örgütleri, dernekler, uluslararası örgütler, çok uluslu şirketler olmak üzere tüm paydaşları bir araya getirerek, bir ağ içinde toplu katılım yoluyla karar vermeye başlamıştır. Pek çoğuna göre bu durum ulus devletin aşınmasına neden olmaktadır. Zira uluslararası örgütler ve merkez devletler tarafindan yönlendirelen ulus devletler küçülmekte yetki alanları daralmakta, üretim özelleşirken, tüketim odaklı yeni bir ekonomik büyüme çağına geçilmektedir (Daldal, 2010: 190-191).

Kapitalizm, zaman içinde yaşam standardını yükseltmek ve tüketici ihtiyaçlarını kısa vadede karşılamak üzere toplumsal kaynakların verimli kullanımını teşvik etmek için tasarlanmıştır. Zira kapitalizm, zaman içinde evrim geçiren ve devam eden, farklı şekillerde su yüzüne çıkan ekonomik ilişkilerin yönetim şeklidir. Kapitalizm üretkenliği teşvik etmek için tasarlandığından, gelir ve servet eşitsizliklerini arttırması beklenebilir ve yeni bir teknolojideki ilk hamleler, onlarca yıl boyunca avantajlarını koruyabilir (Scott , 2006: 2,9,10).

\subsection{Sürekli Satın Alma Duygusunu Körükleyen Tüketim Kültürü}

Kapitalist üretimin genişlemesi, bilhassa 20.yüzyılın başlarında bilimsel yönetim ve 'Fordizm'den alınan destek sonrasında, yeni pazarların inşasını ve halkın reklam ve diğer medya yoluyla tüketiciye dönüşmesinin eğitimi ile gerçekleşmiştir (Featherstone, 1990: 6). Ritzer için alışveriş merkezleri, zincir mağazalar, indirim mağazaları, eğlence merkezleri, kumarhaneler, yolcu gemileri, lüks siteler, sanat merkezleri, eğitim merkezleri, hayır kurumları, mega kiliseler vb. tüm bu yerler tüketimin katedralleridir. Tüketim araçlarının büyülü özellikleri, görsel, işitsel, duygusal ayartıcılar haline dönüştürülerek, tüketicileri etkisi altına almakta ve onları büyülemektedir. Oysaki Weber'in iddia ettiği büyüsü bozulmuş ve tadı kaçmış dünya demir bir kafes gibi insanı sarmış ve tüm özgürlüğünü almışken, Ritzer için, tüketimin tekrar tekrar büyülediği bir dünyada birey sahte bir mutluluk ve özgürlük içinde bilinçsizce yaşamaktadır (Ritzer, 2011: 1820).

Wallman'a göre, 1920'lere doğru aşırı üretim sorunu, ABD'yi bir yol ayırımına getirmiştir. İki şeçenek vardır, ya daha az üretim yapılacak ya da toplum daha fazla tüketime teşvik edilecektir. Daha fazla tüketimin daha iyi olduğu düşüncesinde olan Hoover gibi politikacıların yanısıra, General Motors CEO'su Alfred Sloan gibi sanayicilerde yetersiz tüketimin esas mesele olduğu görüşünü savunmuşlardır (Wallman, 2018: 82).

$\mathrm{Bu}$ gelişme ünlü Alman filozof Weber'in tezinin tam tersi görünümdedir. Zira özünde, Weber öncelikle belirli dini fikirlerin (öncelikle Kalvinizm) bir 'kapitalist ruhla' nasıl uyumlu olduğunu ve bunun kapitalizmin yükselişine nasıl katkıda bulunduğunu açıklamakla ilgilenmiştir. Weber, yaptığı araştırmalarda Benjamin Franklin'in dindar bir adam olmamasına rağmen, katı bir bir Calvinist olan babasının onu yasalara uygun olarak yapıldığında ticaretten para kazanmanın erdem ve yeterliliğin ifadesi olduğuna inanması için yetiştirdiğini keşfetmiştir. Weber, kapitalizmin yükselişinde üretiminde dini fikirlerin yanı sıra sanayi devrimi, serbest bir pazarın yükselişi ve günlük yaşamın artan ticarileşmesi gibi tarihsel ve maddi koşulların da önemli olduğunu kabul etmiştir. Yaptığı araştırmalar sonrası Weber, kapitalist girişimcinin (ideal) özelliklerini şu şekilde tanımlamaktadır:

\section{Abartılı ve gereksiz harcamalardan kaçınır;}

- Pozisyonunun (statüsünün) getirdiği güçten
yararlanmaktan kaçınır;

Elde ettiği sosyal tanınmayı kullanmaktan çekinir;

Hoşgörü ve ölçülü davranış ile damgalanmış katı bir disiplinin (iç dünyevi çilecilik) ile yaşar;

Kadın ya da erkek işini iyi yapmanın duygusuyla 'yersiz' herhangi bir kazanç sağlamayı talep etmez (Chriss, 2019: 53).

Ancak, Protestan ahlakı günümüzde çözülmüştür. İlk kez İngiliz Mandeville (1715) tarafindan yazılan Arılar Masalı: ya da Bireyin Ahlaksızlığı Toplumun Kazancıdır isimli hiciv tarzı eser, lüks ve refah içinde yaşayan bir grup arı hakkındadır. Ancak, arılar, ahlaksız, açgözlü ve savurgan hayatlarından vazgeçerek, sade, basit, dürüst ve sakin bir hayat yaşamaya başlarlar. Masalın sonunda, arıların yaptıkları bu fedakârlığın, lüks yaşamdan vazgeçmenin pek de iyi olmadığı kanaati hakimdir. Bu mantık tüketim kültürünü de tetikler, daha fazla satın almak daha lüks içinde yaşamak, daha fazla mutluluk ile özdeşleşir. Zira tüketime teşvik 20.yüzyılda başlamad1, 19.yüzyılda, ABD'de tek kullanımlık tıraş bıçakları ile yakaları beyazlatmanın meşakkatli olduğu bu yıllarda tek kullanımlık gömlek yakaları ve manşetleri bile vardı. Teknolojik gelişmeler, üretim verimliliğini ve kalitesini artırırken, diğer taraftan eski ve modası geçmiş ürünlerin 
terk edilmesini sağladı. Şöyle ki, 1760’lar (da) Hargreaves iğ makinesini icat ettiğinde, eski iğ makinesine kıyasla yirmi kat daha verimli iplik eğirme dönemi başlamıştır. Nitekim eski iğ makinesi piyasadan kaybolurken, yenisi yerini hızlı bir şekilde almıştır (Wallman, 2018: 87).

Fransız filozof, Comte, Karl Marx'ın kapitalizmin ile ilgili düşüncelerinde neden yanıldığını şu şekilde ifade eder. Ona göre, Marx, sömürü ve yabancılaşma gibi kavramları ile temelde ekonomiye ahlak getirmek istemektedir. Zira bu kavramlar ahlakla ekonominin sinırındadır ve birinden diğerine geçişi sağlarlar. Marx, baştan itibaren tamamen yalın bir şekilde gördüğü ekonomik sistemi ne insanların vicdanına bırakılarak ne de yeni bir bölüşüm sağlayarak düzenlenebileceğine inanmadı. Ona göre eşitsizlik ancak, insanları ekonomik olarak eşit yapacak yeni bir ekonomik sistem üreterek mümkün olabilirdi. Marx, antropolojisi doğru olan ancak antropolojik araçlara sahip olmayan bir ekonomik sistem önermiştir. Zira insan yapısı bencildir ve gerçek şudur ki, her bir birey kendi çıkarını ortak çıkarlardan daha üstün tutar. Oysaki kapitalizm, insanları olduklarından daha farklı davranmasını istememekte, oldukları gibi davranmalarını teşvik etmektedir (ComteSponville, 2012: 69-70).

\subsection{Kapitalist Tüketim Odaklı Tüketici Hakları}

Yücel, dijitalleşmenin yeni tüketici haklarını gündeme getirdiğini savunmaktadır. Tabiki en önemli husus kişisel verilerin güvenliğidir, zira bu veriler ahlaki olmayan bir takım amaçlar için kullanılabilmektedir. İnsan yapısı ve bilişsel öğrenme süreci değişmektedir. Algıları ile oynanan bireyler bir tüketim nesnesi haline dönüştürülmektedir. Yakın gelecekte, 50 milyar makinenin birbiriyle konuşacağ tahmin edilmektedir. Daha önce hiçbir dönemde bu kadar elverişli bir gelişim sağlayamayan buluş ve icadın, yıkıcı inovasyon ile insanlığ 1 karşı karşıya bırakması söz konusu olmamıştır. Ürün ve hizmet kavramı farklı boyutlara gelirken, değişen taleplere anında cevap veren sistemler geliştirilmektedir. Şirketler için müşteri sadakati, uzun vadeli başarıyı sağlamanın temel hedeflerinden biridir. Yeniden satın alma sadakatinin önemli bir yönü olan ve her bir müşteriye neyin aynı marka ve ürünü tekrar satın almasını sağladığı hususu ise yapay zekâ yardımı ile bulunabilinmektedir. Müşteri sadakatinin sürekliliğinde bir üründen memnun kalması tek başına yeterli değildir. Bir müşteri, bir ürüne ya da markaya duygusal olarak nasıl bağlanacaktır. Teknoloji beraberinde müşterinin sürekliliği için şirketler yeni çözümler bulabilecek midir? Örneğin, mamülün, üretim sürecinin aşamalarında müşteriye ürün geliştirme ve yapılandırma üzerine söz hakkı tanımak gibi. Acımasız rekabet ortamında, şirketler için müşteri ürün geliştirme sürecinde ortak tasarımcı olabilecektir. Tüketici haklarına saygılı bir sicile sahip, tüketicinin güvenliğini ve sürece katılımı sağlayabilen şirketler en kârlı hale gelirken, ilişkisel sorumluluk ve tüketici hakları gittikçe daha önem kazanacaktır (Yücel, 2015: Fels, Falk ve Schmitt, 2017: 410).

Kapitalist tüketim, kendini dışa vurmayı sürdürebilmek için bir altyapıya ihtiyaç duyar. $\mathrm{Bu}$ altyapının bileşenleri arasında teknoloji ve telekomünikasyon, kurumsal lider olarak küreselleşme, neo-liberal piyasa ideolojisi, uluslararası finans kurumları ile halinden memnun olanlar ve şikâyetçiler, ya da suç ortakları da bulunmaktadır. En önemlisi, bu altyapının diğer bileşeni aile ve tüketici bilimleri mesleğinin bir parçası olarak tüketicidir. Tüketici hakları, genellikle tüketiciyi işin aşırılıklarına karşı korumayı ve tüketicilerin haklarını geliştirmeyi amaçlayan toplumsal harekete işaret eder. Yükselen tüketici hakları, genellikle yapısal şiddetten etkilenen tüketicilerin hakları için savaşır (ev sahibi - kiracı sorunları, konut ayrımcılığı, yaşlı tüketicilerin kötüye kullanılması, finansal kurumlar tarafından kadınlara karşı ayrımcılık ve savunmasız tüketici olarak çocuklar). Bir bakıma, tüketim olgusunun devamlılığını sağlamak ve tüketimin özendirilmesini sürdürmek üzere tüketici ve piyasa arasındaki sorunların çözümünde de tüketici hakları konusu önemli bir yere sahiptir (McGregor, 2003: 1-9).

Neoliberalizm beraberinde tüketim ve tüketicinin korunması olgusunu getirmiştir. Nitekim Bireşmiş Milletler, 1985 yılında 15 Mart'1 Dünya Tüketiciler Günü olarak beyan etmiştir. 1995 yılında ise Türkiye- AB Gümrük Birliği Anlaşması ile yeni bir döneme girmiştir. Nitekim, 1995'te, sırasıyla 4046 sayılı Özelleştirme Kanunu, 4054 sayılı Rekabetin Korunması Hakkında Kanun ve 4077 sayılı Tüketicinin Korunması Kanunu çıkartılmıştır. İlaveten, Fikri-Sınai-Ticari Mülkiyetin Korunması ile Gümrük Mevzuatı için yeni yasal düzenlemeler yapılmıştır. Böylece, ilgili yasaları uygulamak üzere mevcut Gümrük Müsteşarlığı ve Dış Ticaret Müsteşarlıkları yeniden yapılandırılırken; Rekabet Kurumu, Özelleştirme İdaresi Başkanlığı, TPE ile TÜRKAK gibi yeni kamu kuruluşları kanunlarla kurulmuş diğer yandan 1995'ten itibaren Türkiye'de 15 Mart “Tüketici Günü” ve 9 Mayıs “Avrupa Günü” olarak kutlanmaya başlanmıştır (Özgöker, 2014: 7-8).

Nitekim tüketicinin korunması maksadıyla 08.03.1995 tarihinde yürürlüğe giren 4077 sayılı Tüketicinin Korunması Hakkındaki Kanun (TKHK), gelişen koşullara ve TBK ve TTK'ya uyum sağlayamaması ve AB direktiflerine uygun olmaması nedeniyle yeni bir kanunun oluşturulması ile sonlandırılmıştır. 28.11.2013 tarihli Resmi Gazetede yayımlanarak 6 ay sonra yürürlüğe giren, 6502 sayılı TKHK ile tüketici lehine yeni düzenlemeler getirmiştir. $\mathrm{Bu}$ değişiklikler arasında yer alan, 'hareket etme' kavramı; tüketicinin hem sözleşme yaptığı anda hem de sözleşme yapmadan önce sonra korunması yer alır. Benzer şekilde 6502 sayılı TKHK, ayıplı mal konusu daha belirgin şekilde düzenlenerek, satım konusu olan malda, satıcının maddi, hukuki ya da ekonomik ayıp bulunması durumun da sorumlu olacağı konusu açıkça kaleme alınmıştır (Özsoy, 2019: 1-60).

Günümüz dünyasının tüketimin özendirilmesi üzerine kurulu sistemi, esasen insan zihninin nasıl yönlendireceğini çok iyi bilmektedir. Örneğin, bir adam ofisine hızlı bir şekilde ulaşmak veya anlamlı bir kimlik oluşturmak için bir sportif araba kullanabilir. Her iki durumda da, otomobilin kendine özgü fiziksel özelliklerini istediği gibi kullanır. Marx'ın argümanı, bir metanın parasal değerinin (burada otomobilin), bunların hiçbiri tarafindan değil, üretiminde kullanılan sosyal olarak gerekli emek zamanıyla belirlendiği yönündedir. Marx, bir ürünün kullanım değeri üzerinde durmamıştır. Bu, günümüzün meta fetişizminin, bir yüzyıl önce Marx ve diğer klasik politik iktisatçılar tarafından tartışılmış olan aynı meta fetişizmi olmadığ anlamına gelmektedir. Zira günümüzde bir ürünün 
kullanım-değeri ürünü "dünyaya" "duyular yoluyla, neşe, zevk ve arzu ve eğlence" şeklinde topraklanmış bir estetiğe dönüştürmektedir (Cerni, 2007: 2-3).

Tüketimin kültürünün günümüzde taşıdığı anlam, bireyi karşı konulmaz bir hisle tüketime yöneltmektedir. Nitekim tüketimin tüm dünyada yaygınlaşmasında $\mathrm{ABD}$ politikaları etkilidir. Şöyle ki, Richard Nixon, 1959'da Moskova'ya giderek Nikita Kruşçev'i ziyaret etmiştir. ABD ve SSCB arasında nükleer silahlanma hususunda belirgin düzeyde gerginlik olduğu bir dönemdir, bu. Üstüne üstlük, 1959 yılının Haziran ayında New York'ta açılan, Sputnik I isimli uydunun tanıtımı ile SSCB, ABD'ne üstün teknolojisini gösterme firsatı bulmuştu. $\mathrm{Bu}$ duruma karşı yanıt olarak ABD'nin SSCB'de açtığı sergiye, Kruşçev, Nixon tarafindan davet edilmiştir. Amerikan sergisinde mutfağa giren iki lider arasında şöyle bir atışma geçmiştir. Nixon: "Size bu mutfağı göstermek istiyorum." "Bizim California'daki evlerimizin mutfakları bu şekilde." Kruşçev: "Bizim de böyle şeylerimiz var." Nixon: (Bulaşık makinesini işaret eder) "Bizim bu en yeni modelimiz." "Evlere doğrudan kurulabilecek şekilde binlerce üretiyoruz." "Biz ABD'de kadınların hayatlarını kolaylaştırmak istiyoruz." Kruşçev: "Sizin kadınlara karşı kapitalist yaklaşımınıza komünizmde yer yoktur." Nixon: "Kadınlara karşı bu yaklaşımın evrensel olduğunu düşüyorum." "Yapmak istediğimiz şey, ev hanımlarının hayatlarını kolaylaştırmak." Nixon: (evi işaret eder), "Bu ev 14.000 dolara alınabilir ve Amerikaların çoğunluğu 10.000 -15.000 dolar aralığında bir fiyata bir eve sahip olabilirler." Kruşçev: "Bir eve 14.000 dolar harcayabilecek, çelik işçilerimiz ve köylülerimiz var. Sizin Amerikan evleriniz, inşaatçılarınız tekrar satabilsin diye sadece 20 yıl ayakta kalabilecek şekilde üretilir. Biz sağlam yapıyoruz. Çocuklarımız ve torunlarımız için yapıyoruz." Nixon: "Amerikaların evleri 20 yıldan fazla dayanır ancak yinede, yirmi yıl geçince çoğu Amerikalı yeni bir ev ve mutfak ister. O zamana kadar mutfakların modası geçer. Amerikan sistemi yeni icatlardan ve tekniklerden yararlanmak üzere tasarlanmıştır." Ne yazık ki, Rus evlerinde bulaşık makinesi yoktu, Sovyet haber ajansı Tass şöyle bir açıklama bulundu: "Bize bunun tipik Amerikan işçinin evi gibi gösterilmesi Taç Mahal'ın tipik bir Bombaylı tekstil işçisinin evi olarak gösterilmesinden daha doğru değildir.” Bilakis, bu açıklama ABD heyetinin yalan söylediğini değil, serginin görevini yerine getirdiğinin göstergesi olmuştur (Wallman, 2018: 91-92).

Günümüzde hızlı teknolojik gelişmeler, üretimin daha verimli, kaliteli ve hızlı şekilde yapılmasını sağlarken, diğer yandan dijital platformlar, dünyanın neresinde olursa olsun kolayca tüketicilere ulaşabilmektedir. Yaşamımızın her alanında, kitle iletişim araçları vasıtasıyla yayınlanan reklam, özendirici filmler ve yayınlar ile tükettiren kapitalizmin "topluma egemen söylemlerin ortaya çıkmasında" anahtar rol oynarken, aynı zamanda toplumun "tasarruftan arzu kültürüne yönelmesine" adeta ön ayak olmaktadır (Demirel ve Yegen, 2015: 122).

Öte yandan, icat ve yeniliklerin üretime hılı yansıması ile artan makineleşme ve azalan istihdam beraberinde artan üretim verimliliği çalışan yoksulluğuna ve sosyal hakların erimesine neden olurken, tüketici haklarının yükselişini getirmektedir. Kapitalizm-tüketim ilişkisinde yükselen tüketici haklarına yönelik olarak bir örnek vermek isterim. 2017 yılının Mayıs ayında iki yaşındaki ABD’li bir çocuk,
İsveç menşeli mobilya şirketi IKEA tarafindan üretilen, 76 santimetrekarelik Malm marka dolabın altında kalarak hayatını kaybetmiştir. Kusur sonucu çocuk ölümlerine ilişkin daha önce hiç görülmemiş tutarda bir tazminat meblağını (46 milyon dolar) IKEA firması, ABD'li çifte öderken, bu trajik olayın sonucu yaşanan kaybı hiçbir anlaşmanın telafi edemeyeceğini ancak böyle bir anlaşmaya varıldığından dolayı minnettarlıklarını iletmektedir (MSN Haber, 08.01.2020).

Benzer şekilde, dünyaca tanınmış Alman ilaç ve kimya şirketi Bayer AG, 2018 yılında ABD'li Monsanto Co. İsimli şirketi 63 milyar dolara satın almıştır. ABD’li çiftçi çiftin, California mahkemesine açtığı davada yabancı otların temizlenmesinde kullanılan Roundup Ready isimli ilacın kanser riskini uyarması nedeniyle, Bayer firması 2 milyar 55 milyon dolar tazminata çarptırılmıştır. Bayer AG firması karara itiraz edeceğini duyururken, çiftin ilacı 25 yıldır bahçelerinde kullandığı iddia etmiştir. Bir üst mahkemeye cezaya itiraz eden Bayer AG lehine, California üst mahkemesi, 2 milyar dolar olan tazminat cezasını 86, 7 milyon dolara indirmiştir. Böylece, davacılar Alva ve Alberta Pilliod, zararı karşılayıcı tazminat olarak yaklaşık 17 milyon dolar ve cezai tazminatta olarak ise 69 milyon dolar alacaklar ancak bu duruma memnun olmayan Bayer AG temyize gideceğini bildirmiştir. Nitekim Bayer, glifosat esaslı ürünün potansiyel sağlık riskleri konusunda 13.000 civarında ABD davası ile karşı karşıya kalmıştır (Sabah, 15.05.2019; DW News, 26.07.2019). Bayer'in glifosatın alternatifini bulup bulamayacağı, ABD pazarında mücadele edip edemeyeceği ise hala bir muamma olmakla birlikte, Bayer bir Amerikan firması olsaydı, tüketici hakları ve tüketici mahkemeleri ne yönde karar verirdi, bilemiyoruz.

Nitekim tüketici haklarının artan önemi hususunda bir örnekte Türkiye'den verilebilir. Ankara'da yeni evlenen bir çiftin, nikâh töreni görüntülerini çeken bir firmanın töreni ses olmadan sadece görüntü ile kaydetmesi sonrası, çift manevi tazminat davası açar. Tüketici mahkemesi, firmayı kusurlu bularak, çifte 6 bin lira manevi tazminat vermesine hükmeder. Mahkeme bu kararı ayıplı hizmet kapsamında değerlendirmiştir (NTV, 29.09.2019).

Türkiye'den diğer bir haber ise “Tüketici Mahkemesi'den emsal karar" olarak yayımlanmıştır. Alman Porsche marka araç sahibinin aracına çarpılması sonrası ağır hasar alması ile başlayan sigorta şirketi ve mal sahibi arasındaki süreç haberleştirilmiştir. Sigorta şirketi tarafindan 'ibraname' imzalatılarak, ağır hasar için 390 bin lira Porsche sahibine ödenmiştir. Mahkeme, 2012 model arabanın ağır hasar aldığı tarihteki ikinci el piyasa değerinin 520 bin olduğuna karar verirken, ibranamenin iptaline ve kalan 130 bin liranının faizi ile mağdura ödenmesine karar vermiştir (Milliyet, 04.11.2019).

Ülkemizde her ay Tüik tarafindan yapılan Tüketici Güven Endeksi ve Tüketici Eğilim Anketi, hane halkının satın alma eğilimini ve güvenini ölçmektedir. Türkiye İstatistik Kurumu (Tüik), Tüketici Eğilim Anketi ve Tüketici Güven Endeksi adı altında bir anket çalışması yayınlayarak, Türkiye'deki hane halkının eğilimini ölçmektedir. Esasen, Tüketici Güven Endeksi, ekonomiye ilişkin önemli veriler sunmakla birlikte, psikolojik ekonomi disiplini çerçevesinde tüketici güveni konusunu, ekonomi açısından değerlendirmektedir. Zira hane halkı davranışlarının nasıl değiştiğini bilmeyi istemek, satın alma gücü olan bireylerin 
satın alma isteğini canlı tutmak isteğindendir. $\mathrm{Bu}$ ise ülkelerin ekonomik büyümelerinin sürdürülebilirliği noktasında çok önemlidir (Tunalı ve Özkan, 2016: 54-67).

\section{Sonuç}

Hiç kimse, kapitalizmin ilk defa 16.yüzyılda Batı Avrupa'da kalıcı olarak kök saldığını inkâr edemez, aynı zamanda kök saldığı İngiltere, Hollanda, Kuzey Fransa ve Kuzey Batı Almanya'da ekonomik büyümeye neden olmuştur. Nitekim, zamanla siyasi ve askeri güce çevrilen kapitalizm, Avrupa devletlerinin 18. yüzyılın sonundan itibaren dünyanın geri kalanına hükmetmesini mümkün kılmıştır. Nitekim, Avrupa'ya diğer kültür ve medeniyetlere karşı derin bir üstünlük duygusu kazandırmıştır.

Babür İmparatorluğu'nun devasa büyüklükteki değerli hazinelerini ele geçirmek için 23 Haziran 1753'de Hindistan'da İngiltere ve Fransa kıran kırana savaştılar. İngiltere'nin kazanıp, Hindistan'ı kolonileştirdiği savaşın isme Plessey'dir ve sonuçları ile tarihte önemli bir yere sahiptir. Hindistan'dan getirilen büyük servet, İngiltere'de dokumacılık üzerine buharlı makinelerin icat edilmesini tetiklemiştir. Böylelikle, İngiltere Hindistan'dan getirdiği ham ipeklileri, buharlı dokuma tezgâhlarında işleyip, işlenmiş ürünleri ise kolonilerine satarak ekonomik ve siyasi gücünü perşinlemiştir. Müteakip süreçte, sanayi devrimi ile sinıf mücadelelerinin sadece feodalizmin düşüşünü değil, kapitalizmin oluşumunu da belirlemiştir. Bir bakıma kapitalizm kendisini yeniden üretmiş, daha da güçlenmiştir. İmalat sanayi üretimde montaj hattı ise, üretim verimliliğini artırırken, yarı vasıflı çalışanların istihdamını sağlamıştır. İkinci Dünya Savaşı sonrası dünya genelinde yaygınlaşan Keynesyen ekonomi ise üretim ve tüketim arasında dengenin sağlanmasını, tam istihdam ve devletin emek piyasalarına müdahalesi politikaları ile sağlamıştır. Böylece 20. Yüzyılın başlarında tüketimi teşvik eden politikalar uygulanmaya başlamıştır. Zira, alım gücü yükselen çalışanlar, aynı zamanda bir tüketim birimi haline gelmiştir.

Marx'in emek değer teorisi ile ortaya koyduğu emeğin kendi değerinden daha fazla değer ürettiği ve girişimciye kâr sağladığı iddiası ise günümüzde Schumpeter'ın bir girişimcinin başarılı yenilikler getirerek ekonomik kazanç elde edebileceğine söylediği İnovasyon Kâr Teorisi arasındaki tartışma devam etmektedir. Nitekim nüfusu günden güne azalan gelişmiş ülkeler ile emek yoğun imalat sanayi üretimini sürdüren Çin arasında artan bir rekabet söz konusudur. Alman firması Siemens Amberg fabrikasında dijital ortamda karanlıkta üretim yapmaktadır. Neredeyse hiç insanın çalışmadığı (\%75 makine) enformasyon teknolojileri ile yapay zekâ ve endüstriyel robotların yer aldığı akıllı fabrika uygulaması, 1989 da başlatılmıştır. Keza, gelişmiş ülkeler, akıllı fabrika sistemi ile üretim verimliliğini ve miktarını artırsalar da maliyetler istenen düzeyde değildir. Oysaki, küresel imalat merkezi konumuna gelen Çin'de pekçok tanınmış otomobil firmaları gibi Tesla'da üretim merkezi kurmuştur. Zira bir endüstriyel robotun çalışma ömrü, bir insanınkinin çok altındadır ve makineler yeni bir kirlilik ve enerji ihtiyacı karşımıza çıkarmaktadır ve istenen maliyette çalışmamaktadırlar. Diğer yandan, küresel ticaret savaşları o derece artmıştırki, Çinli akıllı telefon markası Huawei ile ABD arasındaki ticaret savaşı google tarafından Huawei firmasına uygulanan ambargo nedeniyle kendi işletim sistemini bulmak için çalışan şirketin satışlarını etkileyip etkilemeyeceği hususunda yeni tartışmaları gündeme getirmektedir. Bunlara ilaveten gerek Apple, gerekse Samsung çokuluslu şirketlerinin Çin'deki pazar paylarının $\% 1$ 'in altında kalmasını bahane ederek üretim tesislerini Hindistan'a taşıması ise başka bir muammadır. Bütün bu ticaret savaşları, tüketici haklarını daha da yükseltmektedir. Zira bir ürünün ekonomik sürdürülebilirliği ve satış payı, tüketicinin o ürüne güvenmesi ile son derece yakından ilişkilidir. Bilhassa çok uluslu şirketlerin birbiriyle kıyasıya mücadele ettiği günümüzde tüketici hakları ve tüketici güveni konularının önemi artmakta ve uluslararası boyuta taşınmaktadır.

Dünya Bankası, küresel büyüme beklentilerini 2019 ve 2020 yılları için düşürürken, henüz pandemi sürecine ilişkin gündemi yoktu. Zira bu düşüş artan ticaret savaşları, yükselen tarifeler ve milliyetçi akımlar ile ilgili bir durumdu. Nitekim pandemi süreciyle birlikte teknoloji milliyetçiliği gözle görünür hale gelmiştir. Bilhassa Çin'li şirketlerden Tik Tok ve Huawei için ABD, bazı tedbirleri uygulamaya koymuştur. Huawei firmasının Çin Komünist partisi ile yakından ilişkisi olduğunu ve veri güvenliği hususunda güvenilmez olduğunu açıklayan ABD Başkanı Trump, İngiltere'yi etkilemeyi başarmıştır. Hindistan ise, Çinli kısa video oluşturma ve oynatma sosyal medya platformunu Tik Tok firmasını ülkesinde milli güvenliği tehdit ettiği gerekçesiyle engellemiştir. Tik Tok firmasının ABD'de durumu ise halen çözülememiştir. Kişisel kanaatime göre bilhassa sosyal medya platformları ve teknoloji şirketleri arasındaki kıyasıya rekabet yeni bir dönemi beraberinde getirecektir. Önde gelen bu şirketlerin ABD'li olanları Pentagon ile yakınken, Çin'li şirketler ise Çin Komünist partisi ile yakındır. Yeni dönemde hızlı veri analizi ile tüketici taleplerine en kısa zamanda adapte olan, maliyeti düşük üretim ve hız sağlayan, ürünlerini ve hizmetlerini satın alan devletin hukukuna saygı gösteren ve müşterilerini kendi vatandaşı gibi kabul eden firmalar ipi göğüsleyecektir

Her nekadar devletler açısından ekonomik büyümeden ziyada ekonomik daralma söz konusu olsada, ABD'li çok uluslu şirketler hiç olmadığı kadar hızlı büyüyerek yeni rekorlar kırmayı başardılar. Pandemi sürecinde ABD en zengin 12 kişisi servetini toplamda 1 milyar dolara taşımıştır. 18 Mart 2020 tarihinden bugüne 283 milyar dolar ek servet ile \% 40 büyüyen ABD'li firmaların aksine ABD ev halkinin geliri ise 1950 den beri en düşük seviyeye ulaşarak yüzde 5.6 erimiştir. Bu firmalar arasında en dikkat çekici sıçrama ABD merkezli e-ticaret ve bulut-bilişim şirketi Amazon olmuştur. Bilakis, ABD’de işsizlik ve gelir kayıpları artan halk, seçimler öncesi sivil itiatsizlik yapmış ve marketler yağmalanmıştır.

Öte yandan, Aydınlanma sonrası, aklın artan önemi ve bireyin kendisi için en doğrusunu kendisinin bileceği yönündeki ahlaki sistem, sanayi sonrası modern toplum beraberinde kendi mutluluğunu herşeyin üstünde tutan yeni bir neslin inşasında çok önemli bir zemin hazırlamıştır. Bu doğrultuda tüketim amaçlı olarak pompalanan özgür birey meteforu, her türlü esaret biçimini, acıyı, çok çalışmayı ve sabrı önemsizleştirirken, (Weber'e göre kapitalizmin ruhunu taşımayan Doğu toplumları da dahil) yerel, geleneksel ve kültürel etkiler bir tarafa bırakılarak tüketim 
bağımlılı̆̆ının yerleştirilmesinde kullanılan en önemli mottodur. Ancak, kapitalist sistem, ihtiyacından fazla tüketen, daha az çalışan ve hızla artan dünya nüfusu ile başa çıkamazken, tüketici hakları ve çevre hakları gibi konular alternatif olarak yükselmektedir. Zira çevresel felaketler ve artan kirlilik, işsizlik ile salgın hastalıklar dünyamızı hiç olmadığı kadar büyük bir tehlikenin içine sokarken, küresel tek piyasa ideali ile devlet kapitalizmi arasında yeni bir krizi ateşleyecektir.

\section{Kaynakça}

Akdağ, G. (2015). Gözetim Toplumu Teorilerinin Tarihsel ve Teorik Bir Incelemesi. Yüksek Lisans Tezi. Aydın: Adnan Menderes Üniversitesi.

Alaimo, C. (2014). Computational Consumption: Social Media and The Construction of Digital Consumers. (Erișim: 06.06.2020), http://etheses.1se.ac.uk/975/1/Alaimo_Computationa 1_Consumption.pdf

Aslan, A.O. (2015). Bir Çalışma Alanı ve Siyasi Bir Proje Olarak Kalkınma Yönetimi. Yüksek Lisans Tezi. Ankara: Hacettepe Üniversitesi.

Attali, J. (2017). Geleceğin Kısa Tarihi. T. Ilgaz (Çev). İstanbul: İmge.

Aydın, Y. \& Araman, S. (2018). Konjonktür ve Kriz Teorileri : Marx, Keynes ve Schumpeter. Nişantaşı Üniversitesi Sosyal Bilimler Dergisi, 6(1), 45-67.

Bahçe, S. (2011). Kapitalist Kriz ve Sosyalist Mücadele: Çöküş Teleolojisinin Çöküşü. Mülkiye Dergisi, 35 (271), 175-206.

Bakırtaş, İ. \& Haydaroğlu, C. (2015). Orta Doğu Petrollerinin Politik Ekonomisi. 38. Uluslararast Asya ve Kuzey Afrika Çalışmaları Kongresi, 279304.

Balta, E. (2019). Tedirginlik Çă̆ı. İstanbul: İletişim Yayınları.

Baudrillard, J. (1998). The Consumer Society. London: SAGE Publications,

Baudrillard, J. (2004). Tüketim Toplumu. Hazal Deliceçaylı ve Ferda Keskin (Çev.). İstanbul: Ayrıntı Yayınları

Bauman, Z. (1999). Çalışma, Tüketicilik ve Yeni Yoksullar. Ümit Öktem (Çev.). İstanbul: Gündüz Basım.

Boratav, K. (2019). Sermaye Hareketleri ve Türkiye'nin Beş Krizi. Çalışma ve Toplum, (1), 311-324.

Brown, W. (2018). Halkın çözülüşü, Neoliberalizmin Sinsi Devrimi. B. E. Aksoy (Çev.). İstanbul: Metis Yayıncilık.

Carbonero, F., Ernst, E. \& Weber, E. (2018). Robots Worldwide: The Impact of Automation on Employment and Trade. International Labour Office, Working Paper, (36), 1-14.

Cerni, P. (2007). The Age of Consumer Capitalism. Cultural Logic (s.1-28) (Erişim: 21.06.2020), http://clogic.eserver.org/2007.
Chriss, J.J. (2019). Weber's Protestant Ethic Thesis in Five Steps. In: Academicus International Scientific Journal, (s.51-65) (Erişim: 30.01.2020), https://www.academia.edu/39773560/Webers_Prote stant_Ethic_Thesis_in_Five_Steps.

Comte-Sponville, A. (2012). Kapitalizm Ahlaki midir? Dilek Yankaya (Çev.). İstanbul: İletişim Yayınları

Çelik, A. \& Küçük, A. (2020). Tüketim Toplumunun Çevre Sorunlarına Etkileri. Econharran Harran Üniversitesi IIIBF Dergisi, 4(5), 1-22.

Çınar, Y.(2018). Erken Dönem Marksistlerinden İngiliz Marksist Tarihçilere: Marksist Tarih Yazımının Devamlılı̆̆ı. Akademik Yaklaşımlar Dergisi, 9(2), $1-16$.

Çinliler Dünya Telefon Pazarını Resmen Ele Geçirdi. Habertürk, (09.05.2019). (Erişim : 30.01.2019), https://www.haberturk.com/iste-akilli-telefon-satisrakamlari-2457148-teknoloji

Daldal, Ş. (2010). Kuralsız Kapitalizm Batağında Emek. İstanbul: Alan Yayıncılık.

Demirel, S. \& Yegen, C. (2015). Tüketim, Postmodernizm ve Kapitalizm Örgüsü. ILEF Dergisi, 2(1), 115-138.

Doğan, E.T. (2012). Zanaatkârlığın Günümüzde Yeniden Yorumlanması : Yeni Zanaatkârlık mı? Çalışma İlişkileri Dergisi, 3(1), 67-85.

Duman, Z. (2016). Tüketimci Kapitalizmin ve Tüketim Kültürünün Eleştirisi. Sosyoloji Dergisi, (33), 15-36.

Efendi, A.M. (2000). Bahtiyarlık: Nuri Sağlam (Hazırlayan), Ankara: Türk Dil Kurumu Yayınları.

Erdoğdu, S. \& Kutlu, D. (2014). Dünyada ve Türkiye'de Çalışan Yoksulluğu: İşgücü Piyasası ve Sosyal Koruma Politikaları Bağlamında Bir Değerlendirme. Çalışma ve Toplum, (2), 63-114.

Ergun, C. (2007). Jacques Attali, Geleceğin Kisa Tarihi. Toplum ve Demokrasi, 1(1), 172-176.

Esin, P. (1982). İşbölümü, Yabancılaşma ve Sosyal Politika. Ankara: Ankara Üniversitesi Siyasal Bilgiler Fakültesi Yayınları.

Estlund, C. (2018). What Should We Do After Work? Automation and Employment Law. The Yale Law Journal, (128), 254-326.

Estes, C.L. \& Phillipson, C. (2002). The Globalization of Capital, The Welfare State, and Old Age Policy. International Journal of Health Services, 32(2), 279-297.

Faik Şimart Beni. Youtube (13.06.2020). (Erişim: 15.06.2020).

https://www.youtube.com/watch?v=BA Qdc1uG8Y

Featherstone, M. (1990). Perspectives on Consumer Culture. Sociology, 24(1), 5-22.

Fels, A. , Falk, B. \& Schmitt, R. (2017). User-driven Customization and Customer Loyalty: A Survey. Procedia CIRP, (60), $410-415$. 
Foucault, M. (2016). Özne ve İktidar. İstanbul: Ayrıntı Yayınları.

Freeman, M. (2016). Neoliberal Politikalar ve İnsan Hakları. Şafak Evran Topuzkanamış (Çev.). D.E. ̈. Hukuk Fakültesi Dergisi, 17( 2), 165-188.

Gerçil, G.S. (2004). Küreselleşme ve Çok Uluslu İşletmelerin Çalışma İlişkilerine Etkileri. Dokuz Eylül Üniversitesi Sosyal Bilimler Enstitüsü Dergisi, 6(1), 147-157.

Güllüpınar, F. (2012). Eşitsizlik ve Toplumsal Tabakalaşma Açısından Vatandaşlık Üzerine Sosyolojik Bir Analiz. Ankara Üniversitesi Sosyal Bilimler Fakültesi Dergisi, 67(1), 81-109.

Gevgili, A. (1972), Türkiye'de Kapitalizmin Gelişmesi ve Sosyal Sinıflar. İçinde: Sosyal Siyaset Konferanslarl, 20. Kitap (s.45-96). İstanbul: İ.Ü. İktisat Fakültesi Yayını.

Hülagü, M. (2007). Osmanlı'dan Cumhuriyet'e Misyoner, Ermeni, Terör ve Amerika Dörtgeninde Türkiye. Sosyal Bilimler Enstitüsü Dergisi, 20(4), 429-450.

IKEA, dolabın altında kalarak ölen iki yaşındaki çocuğun ailesine 46 milyon dolar tazmimat ödeyecek. MSN Haber (08.01.2020). (Erişimi: 08.01.2020), https://www.msn.com/tr-tr/haber/gundem/ikeadolab\%c4\%b1n-alt\%c4\%b1nda-kalarak\%c3\%b6len-iki-ya\%c5\%9f\%c4\%b1ndaki\%c3\%a7ocu\%c4\%9fun-ailesine-46-milyon-dolartazmimat-\%c3\%b6deyecek/ar-BBYH8TO

İngiliz banka, 3 bin kișiyi ișten çıkaracak. NTV Ekonomi Haberleri (27.07.2016). (Erişim: 14.01.2020), https://www.ntv.com.tr/ekonomi/ingiliz-banka-3bin-kisiyi-isten0cikaracak,3wKrRKfdU0iSeX6qXMeUDA

İtalyan Unicredit, 8 bin ișçi çıaracak. NTV Ekonomi Haberleri (03.12.2019). (Erişim: 14.01.2020), https://www.ntv.com.tr/ekonomi/italyan-unicredit-8bin-isci-cikaracak,a9YfxPIXEkmDsMPQ-GCDDg,.

Kalelioğlu, E. (2019). Xiaomi, Yeni Fabrikası ile Saniyede Bir Akıllı Telefon Üretebilecek. Webtecno.com. (21.11.2019). (Erişim: 30.01.2020), https://www.webtekno.com/xiaomi-fabrikasaniyede-bir-akilli-telefon-h80232.html

Kanser Eden Tarım İlacına Rekor Fiyat. Sabah. (15.05.2019). (Erişim: 12.02.2020), https://www.sabah.com.tr/dunya/2019/05/15/kansereden-tarim-ilacina-rekor-tazminat.

Karabulut, M. (2008). Tanzimat Dönemi Türk Romanlarinda Alafrangalaşmak. Belleten, (II), 4767.

Karakaş, N. (2010). Osmanlı İmparatorluğu'nun Tasfiye Sürecinde Amerikan Politikası. Tarih Incelemeleri Dergisi, 25(1), 269-296.

Kaube, J. (2020). Max Weber, Çağlar Arasında Bir Yaşam. Öndercan Muti (Çev.). İstanbul: İletişim Yayınları.
Kabaş, T. (2016). Kapitalizm ve Ahlakın Türkiye

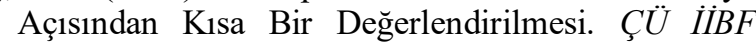
Dergisi, 20(2), 133-147.

Kaval, M. (2019). Tüketim Kültürü ve Tasavvufi Zühd Geleneği. Anemon Muş Alparslan Üniversitesi Sosyal Bilimler Dergisi, 7(1) 151-166

Kılıç, İ. (2011). Kapitalizm, Liberalizm ve Öteki. İçinde: Ankara Hukuk Fakültesi, Zabunoğlu Armağanı, 501515.

Kiely, R. (1999). The Last Refuge of the Noble Savage? A Critical Assessment of Post-Development Theory. The European Journal of Development Research, 11(1), 30-55.

Kupon Çılgınlığı. TLC TV (2020). Anasayfa, Programlar, Kupon Çılgınlığı, 4.Sezon 2.Bölüm. (Erişim: 15.06.2020), https://www.tlctv.com.tr/kuponcilginligi/4-sezon-2-bolum

Kutal, G. (2000). Çok Uluslu Şirketlerin Ulusal Devletler ve Uluslararası Kuruluşlar Tarafindan Sosyal Politika Alanında Denetimi Sorunu. İçinde: Türk Ağır Sanayii ve Hizmet Sektörü Kamu İşverenleri Sendikası Prof. Dr. Nusret Ekin'e Armă̆an (s.7195). Ankara: TUHíS Yayını.

Lundy, L.K., Ruth, A.M., Park, T.D. (2008). Simply Irresistible: Reality TV Consumption Patterns. Communication Quartely, 56(2), 208-225.

McGregor, S.L.T. (2003). Consumerism as a Source of Structural Violence. The Canadian Fair Trade Network. (Erişim: 29.01.2020), http://cftn.ca/sites/default/files/AcademicLiterature/c onsumerism.pdf

Miller, B. \& Atkinson, R.D. (2013). Are Robots Taking Our Jobs, or Making Them? ITIF, (Erişim: 15.08.2019),

[https://itif.org/publications/2013/09/09/are-robotstaking-our-jobs-or-making-them. Online].

Moch, J. (1956). Technology and the Future. Bulletin of the Atomic Scientists, 12(4), 112-119.

Motorola, Nokia ve BlackBerry'e ne Oldu? CNN Türk (24.09.2013). (Erişim: 29.12.2019), https://www.cnnturk.com/2013/guncel/09/24/motoro la.nokia.ve.blackberrye.ne.oldu/724633.0/index.html

Nazım, N. (2004). Zehra. İstanbul: Bordo Siyah Klasik Yayınlar.

Nikah görüntüleri kusurlu kaydeden firmaya 6 bin lira tazminat. NTV (29.09.2019). (Erişim: 25.02.2020), https://www.ntv.com.tr/turkiye/nikah-goruntulerikusurlu-kaydeden-firmaya-6-bin-lira-tazminat,k$\underline{\text { TicSap40OpGsbk40xoHQ }}$

Özgöker, U. (2014). Refah Artışı ve İktisadi Kalkınmanın Temeli Tüketicinin ve Rekabetin Korunması. İçinde: 15 Mart 2014 Dünya Tüketiciler Günü Panel Tebliğleri. İstanbul: Tüketicinin ve Rekabetin Korunması Derneği. 
Özkan, P. (2020). Tüketiciden Sonra Kim Gelecek. Mediacat (12.07.2020), https://mediacat.com/tuketiciden-sonra-kim-gelecek/

Özsoy, R. (2019). 6502 Sayllı Tüketicinin Korunması Hakkinda Kanun Kapsamında Ayıplı Ifa ve Sonuçları. Yüksek Lisans Tezi. Ankara: Ankara Üniversitesi.

Ritzer, G. (2011). Büyüsü Bozulmuş Dünyayı Büyülemek. İstanbul: Ayrıntı Yayınları.

Saklı, A. R. (2013). Fordizm'den Esnek Üretim Rejimine Dönüşümün Kamu Yönetimi Üzerindeki Etkileri. Elektronik Sosyal Bilimler Dergisi, 12(44), 107-131.

Schumpeter, J. A. (1966). Kapitalizm, Sosyalizm ve Demokrasi. (1.Cilt), İstanbul: Varlık Yayınları.

Scott, B.R. (2006). The Political Economy of Capitalism. Harvard Business School Division, 7(37), 1-28.

Sözcü (20.11.2019) Sendika işsiz kalan bankacılar için gazetelere ilan verdi. (Erişim: 15.01.2020), https://www.sozcu.com.tr/2019/ekonomi/sendikaissiz-kalan-bankacilar-icin-gazetelere-ilan-verdi5461317/.

Sennett, R. (2013). Zanaatkar. Melih Pekdemir (Çev.). İstanbul: Ayrıntı Yayınları.

Sevindi, N. (2012) Monet'nin Giverny'deki evini gezmek tablolarda yürüyüşe çıkmak gibiydi. Hürriyet (30.07.2012). (Erişim Tarihi: 10.11.2020), https://www.hurriyet.com.tr/monet-nin-givernydeki-evini-gezmek-tablolarda-yuruyuse-cikmakgibiydi-21096995.

Simmel, G. (2008). Modern Kültürde Çatışma. Elçin Gen (Çev.). İstanbul: İletişim Yayınları.

Soylu, P.Ü. (2015). Türkiye’de İkinci Dünya Savaşı Sonrası İktisadi Politikanın Dönüşümü. Doktora Tezi, Ankara: Ankara Üniversitesi.

Sönmez, S. (2016). Bretton Woods, Fordizm ve Hegemonya. Hacettepe Üniversitesi İktisadi ve İdari Bilimler Fakültesi Dergisi, 34(1), 43-62.

Stambolieva, M. (2015). Welfare State Change and Social Citizenship in the Post-Yugoslav States. European Politics and Society, 16(3), 379-394.

Şan, M.K ve Hira, İ. (2004). Modernlik ve Postmodernlik BağlamındaTüketim Toplumu Kuramları. Bilgi 1(8), 1-19.

Tanpınar, A.H. (1988). 19. Asır Türk Edebiyatı Tarihi. İstanbul: Çağlayan Kitabevi.

Tek Boynuzlu Atın Sırrı. Winx Club - 7. Sezon 22. Bölüm, 2016, (Erişim: 22.04.2020), https://www.youtube.com/watch?v=Zt_5JuAw4Zg

Tesla'dan Çin'e bir yatırım daha! Sözcü (16.01.2020). (Erişim:

15.02.2020), https://www.sozcu.com.tr/2020/otomotiv/tesladancine-bir-yatirim-daha-5571064.

Tunalı, H. \& Özkan, İ.E. (2016). Türkiye'de Tüketici Güven Endeksi ve Tüketici Fiyat Endeksi
Arasındaki İlişkinin Ampirik Analizi. İktisat Politikası Araştırmaları Dergisi, 3(2), 54-67.

Tüketici mahkemesinden emsal 'ibraname' kararı. Milliyet (04.11.2019). (Erişim: 25.05.2020), https://www.milliyet.com.tr/gundem/tuketicimahkemesinden-emsal-ibraname-karari-6071268

Türkcan, E. (1980). I.M.F.'nin Kökenleri. Ekonomik Yaklaşım, 1(3), 37-84.

US Judge Reduces \$2 Billion Monsanto Roundup Verdict Against Bayer. Dw news (26.07.2019). (Erişim: 08.01.2020), https://www.dw.com/en/us-judgereduces-2-billion-monsanto-roundup-verdictagainst-bayer/a-49751667.

Ünal, A. (2011). Çalışma ahlakı kavramına kültürel bir bakış ve Türkiye'de Çalışma Ahlakı. İstanbul Üniversitesi Siyasal Bilgiler Fakültesi Dergisi, 1(44), 125-145.

Wallman, J. (2018). Istif Çă̆ı. Senem Karagözoğlu ve Aytaç Özgören (Çev.). İstanbul: Yıkılmazlar Basım Yayin.

Weber, M. (1992). The Protestan Ethic and the Spirit of Capitalism. Talcott Parsons (Çev). New York: Routledge.

World Development Report, (2019). The Changing Nature of Work. World Bank World Development Report, (Erişim: 05.03.2020), ttp://documents.worldbank.org/curated/en/81628151 8818814423/2019-WDR-Report.pdf.

Wood, A.J., Graham, M. ve Anwar Amir, M. (2020). Minimum wages for online labor platforms. In: The Digital Transformation of Labor Automation, the Gig Economy and Welfare Book (s.74-80). New York: Routledge.

Uçkaç, A. (2010). Türkiye'de Neoliberal Ekonomi Politikaları ve Sosyo-Ekonomik Yansımaları. Maliye Dergisi, 1(158), 422-430.

Yaylak, E. (2017). Sosyal Bilgiler Öğretmenlerinin Eğitimde Sosyal Medyayı Kullanım Düzeyleri ve Görüşleri. Doktora tezi, Denizli: Pamukkale Üniversitesi.

Yllmaz, A. (2012). Türkiye'de Planlama Politikasl ve Yönetimi. Doktora tezi, Ankara: Ankara Üniversitesi

Yılmaz, M.E. (2009). Soğuk savaş sonrasında Yeni Dünya Düzeni. Akademik Bakış, 1(17), 1-14.

Yücel, T. (2015). Dijital Gelecek: Tüketim Değişirse, Hukuk İhtiyacı da Değişir mi? İçinde: Hakan Tokbaş ve Fehim Üçışık (Ed.) Sektörel Bazda Tüketici Hukuku ve Uygulamaları. Ankara: Bilge Yayınevi

Zimmermann, A. (2006). Decolonizing Weber. Postcolonial Studies." 9(1), 53-79.

Zola, E. (2003). Germinal. Volkan Yalçıntoklu (Çev.). İstanbul: Can Yayınları.

Zorlu, K. (02.09.2020). Teknoloji milliyetçiliğin yükselişi. (Erişim: 11.11.2020, https://www.haberturk.com/yazarlar/prof-dr-kursadzorlu/2790700-teknoloji-milliyetciliginin-yukselis 